
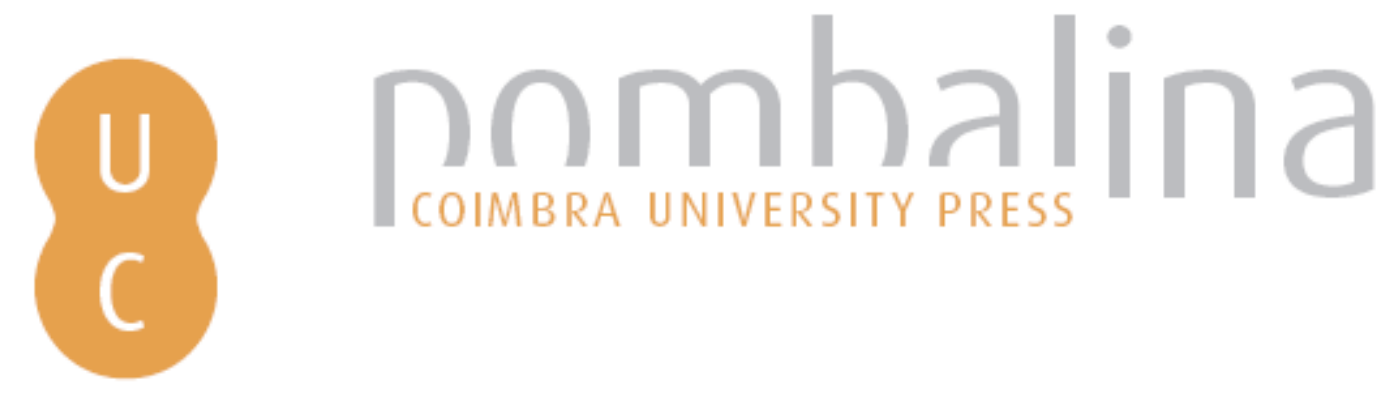

\title{
Valores y virtudes de las mujeres en la Vida de Demetrio
}
Autor(es):
Durán Mañas, Mónica

Publicado por: Imprensa da Universidade de Coimbra; Katholieke Universiteit Leuven

URL

persistente:

URI:http://hdl.handle.net/10316.2/32104

DOI:

DOI:http://dx.doi.org/10.14195/978-989-26-0462-6_6

Accessed : $\quad$ 26-Apr-2023 14:30:25

A navegação consulta e descarregamento dos títulos inseridos nas Bibliotecas Digitais UC Digitalis, UC Pombalina e UC Impactum, pressupõem a aceitação plena e sem reservas dos Termos e Condições de Uso destas Bibliotecas Digitais, disponíveis em https://digitalis.uc.pt/pt-pt/termos.

Conforme exposto nos referidos Termos e Condições de Uso, o descarregamento de títulos de acesso restrito requer uma licença válida de autorização devendo o utilizador aceder ao(s) documento(s) a partir de um endereço de IP da instituição detentora da supramencionada licença.

Ao utilizador é apenas permitido o descarregamento para uso pessoal, pelo que o emprego do(s) título(s) descarregado(s) para outro fim, designadamente comercial, carece de autorização do respetivo autor ou editor da obra.

Na medida em que todas as obras da UC Digitalis se encontram protegidas pelo Código do Direito de Autor e Direitos Conexos e demais legislação aplicável, toda a cópia, parcial ou total, deste documento, nos casos em que é legalmente admitida, deverá conter ou fazer-se acompanhar por este aviso.

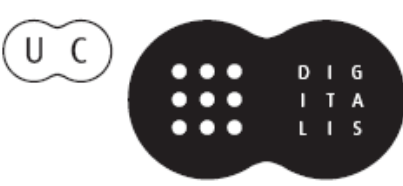




\title{
Puilosophy in Society \\ Virtues and Values in Plutarch
}

\author{
José Ribeiro Ferreira \\ LUC VAN DER STOCKT \\ Maria do Céu Fialho
}

Editors

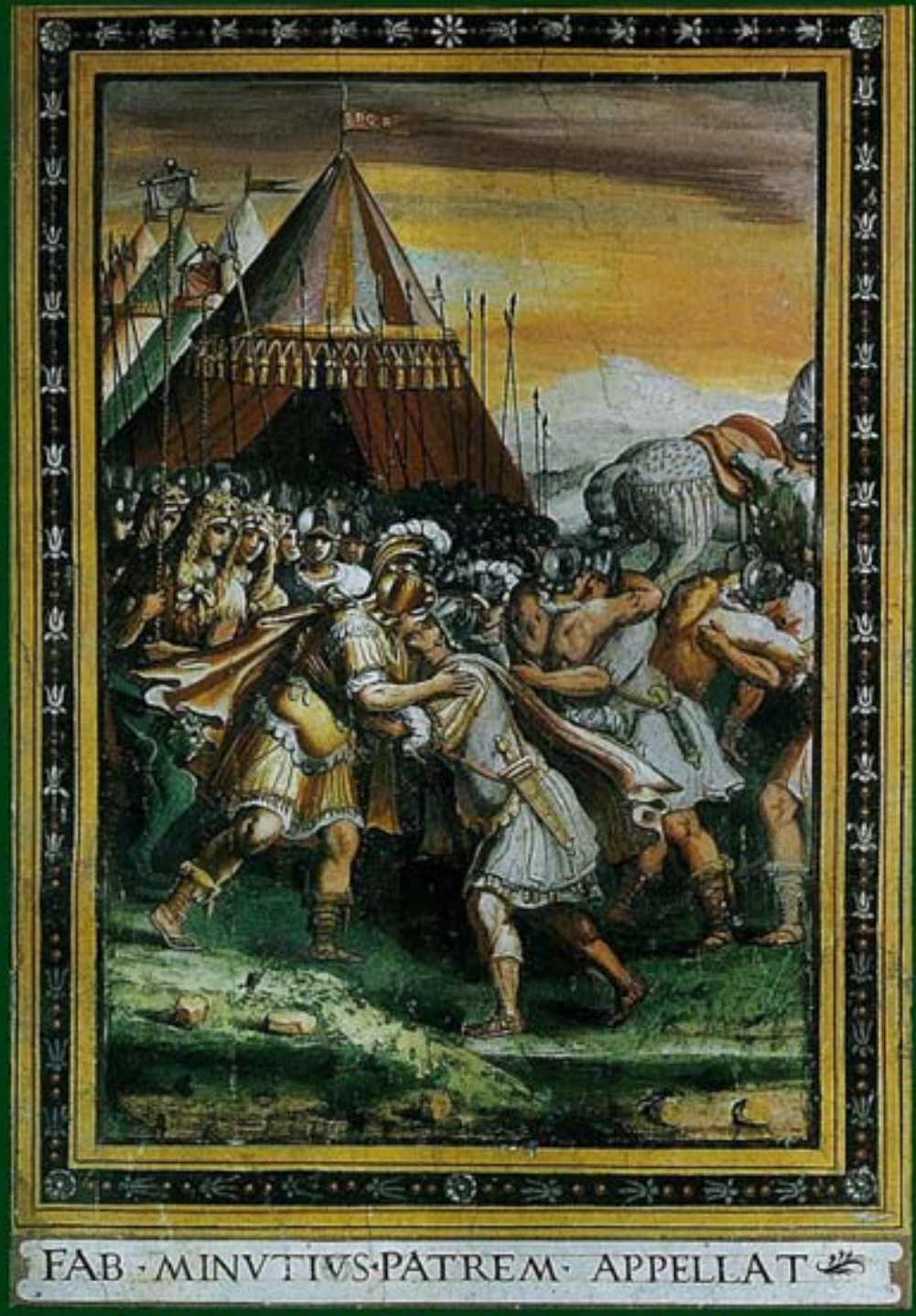

KATHOLIEKE UNIVERSITEIT LEUVEN IMPRENSA DA UNIVERSIDADE DE COIMBRA Leuven-Coimbra, 2008 
(Página deixada propositadamente em branco) 
José Ribeiro Ferreira, Luc van der Stockt \& Maria do Céu Fialho

EDITORS

\section{PhILOSOPHY IN Society}

\section{Virtues and Values in Plutarch}

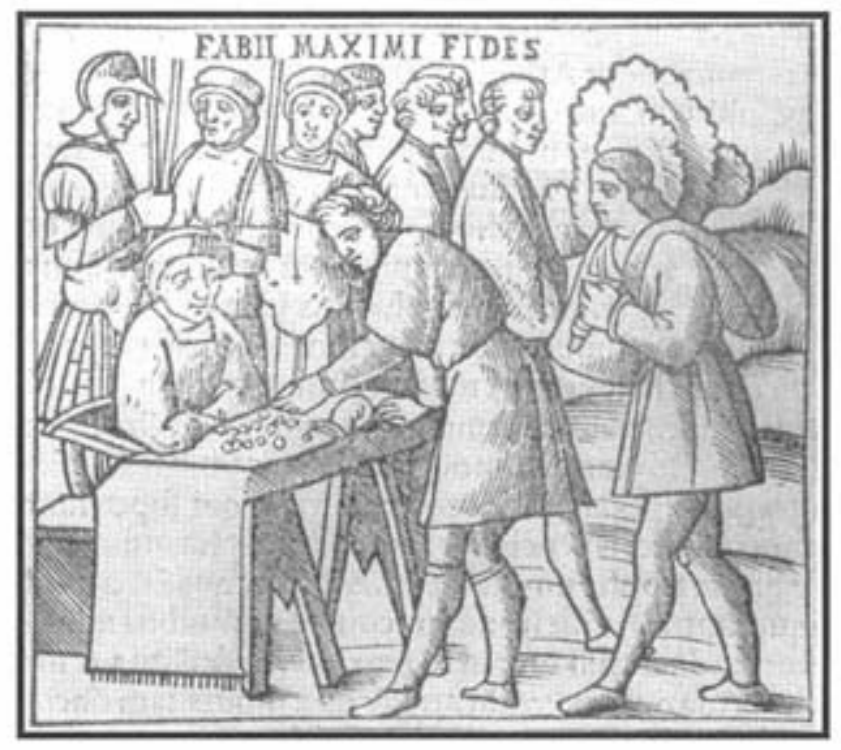

Fabius Maximus' Loyalty

Vitae Plutarchi Cheronei novissime post Jodocum Badium Ascensium longe diligentius repositae maioreque diligentia castigatae, cum copiosiore verioreque indice, nec non cum Aemilii Probi vitis, una cum figuris, suis locis apte dispositis, Venetiis 1516 , fol . 65v

\section{LEUVEN - CoIMBRA \\ 2008}

KATHOLIEKE UNIVERSITEIT LEUVEN

IMPRENSA DA UNIVERSIDADE DE COIMBRA 


\title{
First published 2008
}

\section{(C) Universiteit KATHOlieke Leuven \\ (c) Universidade Coimbra}

\author{
Published by \\ IMPRENSA DA UNIVERSIDADE COIMBRA \\ Imprensa da Universidade de Coimbra \\ Rua da Ilha, $\mathrm{n}^{\circ} 1$ \\ 3000-033 Coimbra (Portugal) \\ Email: imprensauc@ci.uc.pt \\ URL: http://www.uc.pt/imprensa_uc
}

ISBN: 972-989-8074-73-7

Legal Deposit: MA-140-2009

\author{
Printed in Spain by \\ IMAGRAF IMPRESORES, S.A. \\ c/ Nabucco 14 \\ 29006 Málaga \\ Tfno. 952328597
}

\section{Frontispiece:}

Fabius Maximus and Minucius (Francesco da Siena, Grottaferrata, Palazzo Abbaziale). We are grateful to the Archimandrita of the "Monastero Esarchico di Santa Maria di Grottaferrata", P. Emiliano Fabbricatore, for the authorization to reproduce this picture. 


\section{Valores y virtudes de las mujeres en la Vida de Demetrio Mónica Durán Mañas UNIVERSIDAD COMPLUTENSE}

Bien conocido es que los diádocos tomaron la costumbre oriental de casarse con varias mujeres, ya fuera por los dictados de Eros por motivos políticos ${ }^{1}$. Asi, por ejemplo, Pirro, rey de Epiro, tras la muerte de su primera esposa Antígona, contrajo matrimonio con otras muchas debido a asuntos relacionados con el poder:

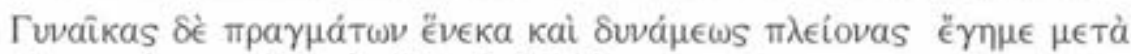

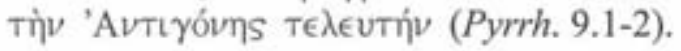

Fue también éste el caso de Seleuco ${ }^{2}$ y de Demetrio, quien - dice Plutarco- "era además proclive a los matrimonios y a tener relaciones con muchas mujeres a la vez":

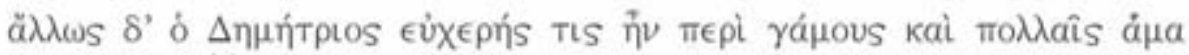

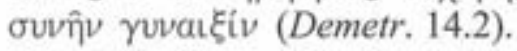

A juzgar por estos asertos, parece que la presencia de las mujeres en la Vida de Demetrio responde fundamentalmente a dos motivaciones por parte del autor. De un lado, al deseo de ofrecer un reflejo de los personajes históricos femeninos que rodearon la vida del monarca y, de otro, al afán de ilustrar una realidad ya anunciada en las primeras líneas del opúsculo: la debilidad de Demetrio por los placeres terrenales. Esta circunstancia invitaba, entre otras cosas, a la comparación de su trayectoria vital con la de Antonio, "siendo ambos igualmente inclinados al amor," bebedores, belicosos, espléndidos, derrochadores y soberbios":

1 Esto tuvo probablemente sus origenes en la politica matrimonial llevada a cabo por el propio Alejandro. Cf. Plut., Eum. 1.

2 Cf. Plut., Demetr. 31.5.

3

$\mathrm{Al}$ parecer, el amor de Demetrio no se limita a las mujeres, sino que el monarca desarrolla una cierta debilidad también por los jovencitos, según se desprende de Demetr. 19.7-8.

José Ribeiro Ferreira, Luc Van der Stockt \& Maria do Céu Fialloo (Edd.), Philosophy in Society - Virtues and Values in Plutarch, Leuven-Coimbra, 2008, pp. 75-98. 


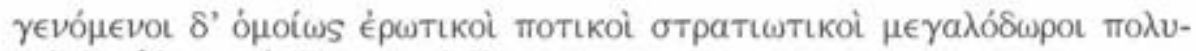

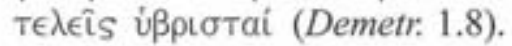

Pero no es ésta la única ocasión en la que se destacan tales inclinaciones. Sabemos que el asunto en cuestión era bien conocido por todos e incluso en esta materia gozaba Demetrio de la transigencia de su padre, a quien "no le molestaban su molicie, su despilfarro y sus festines, pues en tiempo de paz se abandonaba sin medida a estas cosas y, estando ocioso, se entregaba a los placeres licenciosamente y en exceso, pero en la guerra estaba sobrio como los sensatos por naturaleza":

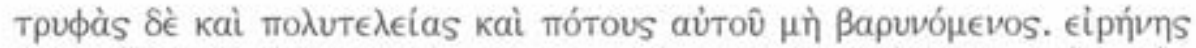

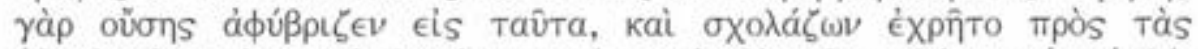

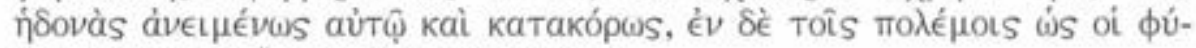

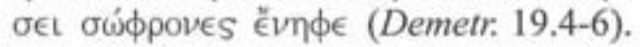

En contraste con esta tolerancia ante los deslices de Demetrio, llama la atención la actitud de Antígono con respecto a su otro hijo Filipo, si hemos de creer la anécdota según la cual, cuando, en una ocasión, el monarca se enteró de que su vástago se hallaba alojado en una casa en la que había tres mujeres jóvenes, le preguntó al aposentador en su presencia si no lo sacaría de la estrechez:

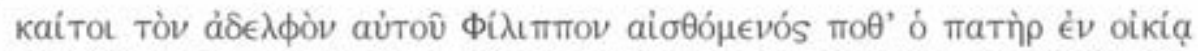

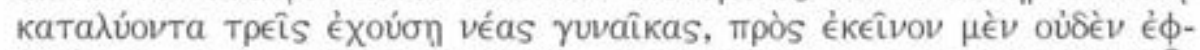

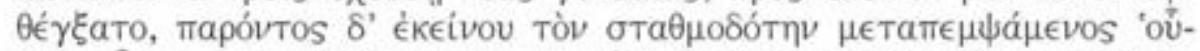

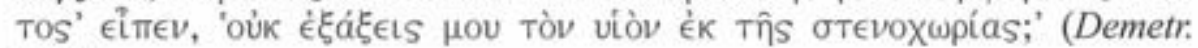
22.6).

Hemos de hacer notar aquí que, cuando Plutarco introduce mujeres anónimas consideradas como colectivo en general, se refiere a un núcleo social desfavorecido cuya presencia se reviste de matices de inferioridad. Se trata, siempre en plural, de mujeres asesinadas (Demetr. 3.5); de rehenes (Demetr. 16.4); de mujeres no correspondidas en el amor (Demetr. 16.7) o de mujeres violadas (Demetr. 24.1). No nos detendremos en el análisis de estas breves menciones genéricas por carecer de un interés significativo a la hora de establecer los valores y virtudes de las mujeres en la Vida de Demetrio.

Pasamos, pues, a observar la presencia femenina en esta obrita de carácter fundamentalmente histórico, que deja entrever, siquiera de soslayo, la situación de algunas mujeres relevantes para la historia de la época helenistica. Las clasificaremos por su nombre y de acuerdo con su estatus social, dividiéndolas para el efecto en función de su vinculo con el protagonista del relato. 


\section{Familiares de Demetrio}

\subsection{Estratonice, madre de Demetrio}

Según informa Plutarco, Estratonice es hija de Corrago, esposa de Antígono y madre de Demetrio y Filipo:

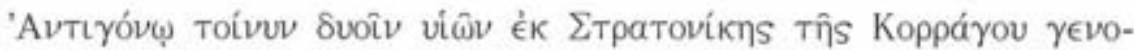

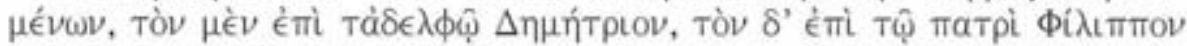

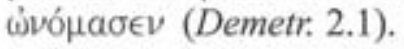

Comienza así propiamente la Vida de Demetrio con una breve referencia a su linaje, según es costumbre ya en el género literario de la biografia. No obstante, el de Queronea inserta a continuación una variante, con probabilidad de procedencia popular, según la cual Demetrio no era verdadero hijo, sino sobrino de Antígono "pues habiendo muerto su padre durante su más tierna infancia y habiéndose casado en seguida su madre con Antígono, fue considerado hijo de éste":

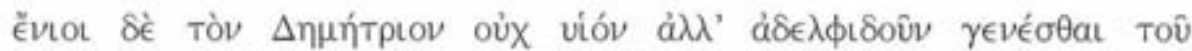

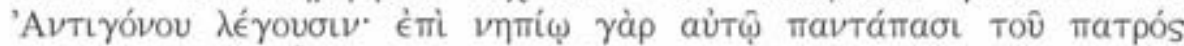

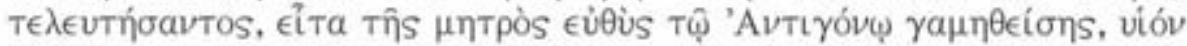

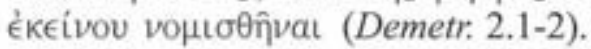

Sea como fuere, Demetrio profesaba un cariño sincero a sus progenitores, dato que parece desentonar con su comportamiento habitual, caracterizado, las más de las veces, por la crueldad y el desenfreno ${ }^{4}$. Así, dice Plutarco, cuidaba de su madre y honraba a su padre más por verdadero amor que por adulación a su poder:

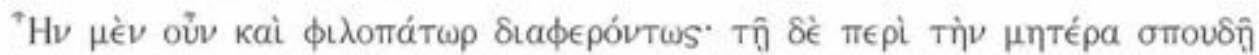

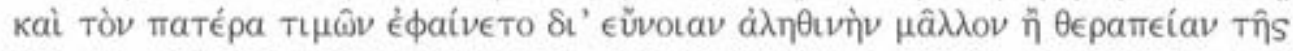

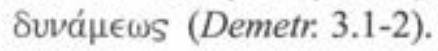

Ciertamente, este detalle entra en marcado contraste con el resto de familias reales de la época, las cuales -como también la de Tesalónica presentada a continuacióncuentan con muchas muertes de hijos, de madres y de mujeres, pues el matar a los hermanos parecia constituir un requisito indispensable para la seguridad de la monarquia:

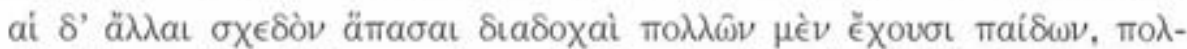

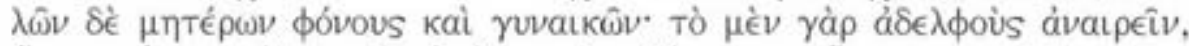

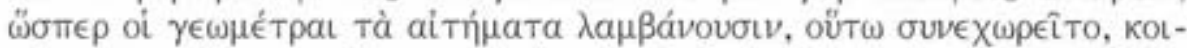

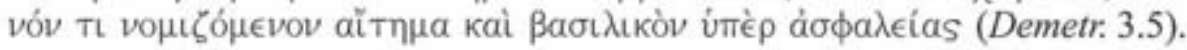

Y en verdad que la familia de Demetrio permanece unida de un modo inusitado, siendo estrechos los vínculos, no sólo entre él y sus padres, sino también entre éstos y sus nietos. A fin de percibir estas relaciones, hemos de centrarnos en un punto 
concreto de la narración en el que no se manifiesta el queronense con toda la claridad deseable, dando lugar, consecuentemente, a distintas interpretaciones por parte de los historiadores. Se trata del momento en que la fortuna de Demetrio cambia de la prosperidad a la desgracia como consecuencia de que Lisímaco ha tomado las ciudades de Asia y Ptolomeo se ha apoderado de Chipre, a excepción de la ciudad de Salamina, que tiene sitiada -dice Plutarco-con "sus hijos y la madre":

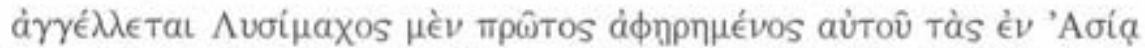

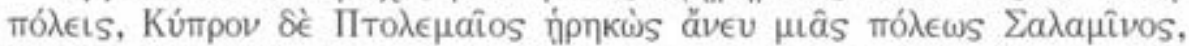

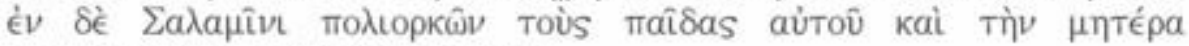

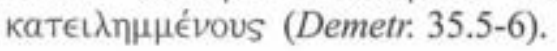

Ahora bien, no cabe duda de que los hijos aquí mencionados son los de Demetrio,

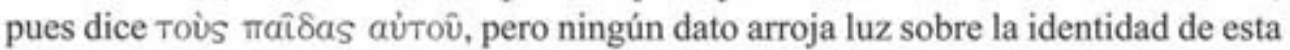
mujer que los acompaña, тท̀v unтté $a$, y no sabemos si es la madre de los niños, si es File o si es la madre de Demetrio. De hecho, poco después vuelve Plutarco sobre el tema con la misma indefinición: la Fortuna se tornó de nuevo favorable para Demetrio y se enteró de que "los hijos y la madre" habían logrado la libertad e incluso habian recibido dones y honores de parte de Ptolomeo:

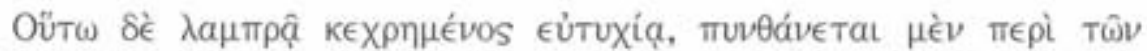

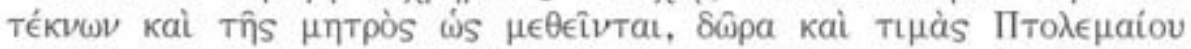
тробӨ́́vтos aủToís (Demetr: 38.1).

Pero lo cierto es que Plutarco acaba de hablar de File en las líneas precedentes $y$, de hecho, esta reina carecía en la época en que Chipre fue capturada por Ptolomeo -corria el año 297 a. C.- de niños pequeños ${ }^{3}$ y gozaba de más de cincuenta años, por lo que parece poco probable que se tratara de ella. Además, Plutarco acostumbra a mencionarla por su nombre propio, especificando a continuación su condición de esposa de Demetrio ${ }^{6}$. Por añadidura, si tenemos en cuenta el testimonio de Diodoro Sículo, resulta claro que, a la muerte de Antígono, Demetrio navegó con su madre Estratonice, residente en la ciudad frigia de Cilicia, y la llevó a Salamina en Chipre, isla que estaba bajo su poder:

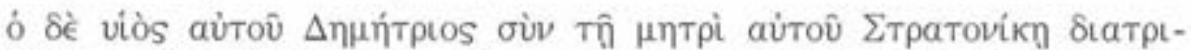

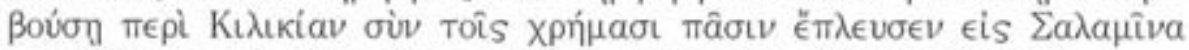

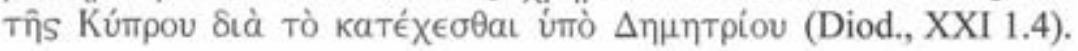

Se despejan así, en nuestra opinión, las dudas que planteaba el pasaje plutarqueo

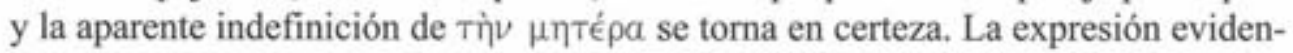


cia, pues, que se trata de la madre de Demetrio ${ }^{7}$ al carecer de un genitivo aủtôv referido a los niños que haria referencia, en su caso, a la madre de éstos. Pero, además, la ambigủedad de la forma podría estar indicando que, en realidad, Estratonice se portaba con los niños como una madre, haciendo hincapié de este modo en los fuertes lazos afectivos que unían a los miembros de la familia de Demetrio, en contraposición con las desveniencias de los demás reinos helenísticos, plenos de crimenes de sangre.

\subsection{Estratonice, hija de Demetrio}

No pocas veces los enlaces matrimoniales responden a móviles de carácter politico o de unificación territorial pero, en ocasiones, también el poder de Eros determina las alianzas en las familias reales. El caso de Estratonice reúne de manera anecdótica ambos tipos de unión -por amor y por conveniencia- si hemos de creer las noticias transmitidas por Plutarco. En efecto, cuando Demetrio se hallaba en dificultades tras haber sido derrotado por los demás reyes coligados contra él y comenzaba poco a poco a recobrarse, Seleuco, un año después de la derrota de Ipsos, pidió a la hija de Demetrio y File, a Estratonice, en matrimonio, aunque él ya tenía un heredero llamado Antíoco de su esposa Apama. El motivo fue eminentemente de alianza territorial: por una parte, la magnitud de su mando le permitia tener muchos sucesores y, por otra, pensaba que necesitaba enlazarse con Demetrio,dado que Lisímaco había tomado a una de las hijas de Ptolomeo para sí mismo y a otra para su hijo Agatocles. Por su parte, Demetrio consideró una felicidad inesperada ser suegro de Seleuco y, tras tomar a la muchacha, navegó rumbo a Siria:

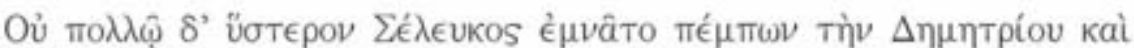

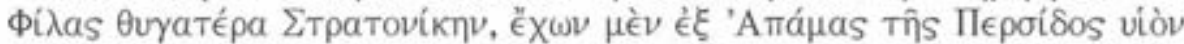

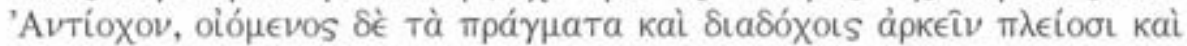

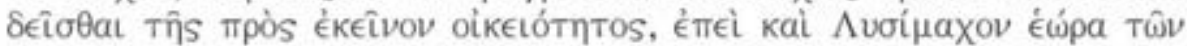

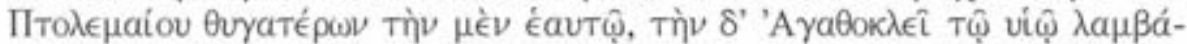

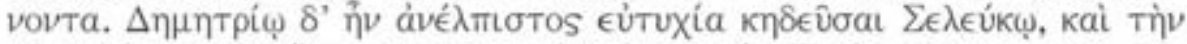

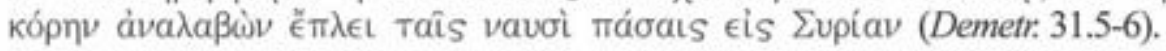

Finalmente, la boda se celebró con esplendor en Roso, en la costa Siria, después de la cual Seleuco llevó a su joven esposa a Antioquia:

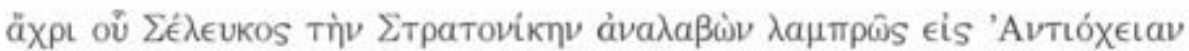
àvéßn (Demetr: 32.3).

Sin embargo, las alianzas matrimoniales no siempre aseguraban la paz y la concordia entre las monarquías. De hecho, se produjo un enfrentamiento entre Demetrio y Seleuco cuando éste le pidió la Cilicia a cambio de dinero y aquél se la negó. Fue entonces cuando Seleuco le exigió la restitución de Sidón y de Tiro y se 


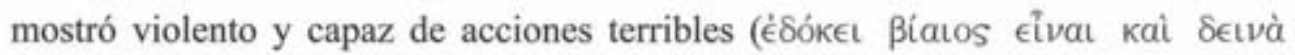
Troteîv, Demetr. 32.7). Pero este primer matrimonio por conveniencia de Estratonice no duró mucho, pues sabemos por Plutarco que, una vez coronado rey de Macedonia, Demetrio se enteró de que Estratonice había sido cedida por Seleuco a su propio hijo Antíoco y que había sido proclamada reina de las provincias altas, siendo aún joven y pese a tener ya una niña de su primer enlace. Cuenta Plutarco que Antíoco se enamoró de su madrastra y este amor lo fue consumiendo ${ }^{8} \sin$ que se atreviera a manifestar la causa de su enfermedad. Finalmente, el médico Erasístrato ${ }^{9}$ halló la raiz de su dolencia y, mediante una estratagema, persuadió al padre de la forma de salvar a su hijo moribundo. Así fue cómo Estratonice pasó de esposa de Seleuco a mujer de Antioco (Demetr. 38$)^{10}$. Sin embargo, los historiadores modernos ${ }^{11}$ optan por una interpretación distinta que antepone los motivos políticos y jurídicos de este nuevo enlace de Estratonice a las causas meramente sentimentales.

A pesar de este vínculo matrimonial, Demetrio y Seleuco siguieron siendo enemigos en una lucha por el poder territorial. Cuando Demetrio cayó definitivamente en desgracia, decidió entregarse a Seleuco quien, al principio, se mostró benevolente con él. Pero luego, le persuadieron de que debía desconfiar y lo tuvo prisionero desde entonces. Con todo, se le permitia al reo disfrutar de las visitas de sus amigos que le llevaban palabras benignas y le pedian tener confianza en la idea de que cuando llegara Antíoco con Estratónice todo se arreglaría:

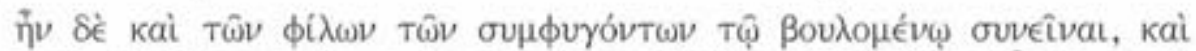

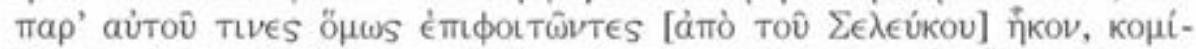

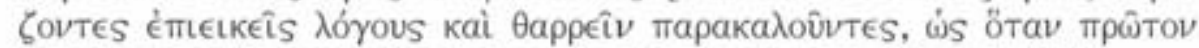

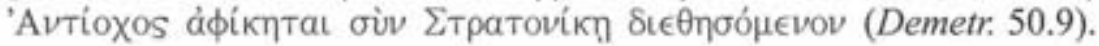

Entretanto, Antígono, hijo de Demetrio, y muchos otros a excepción de Lisímaco rogaban a Seleuco indulgencia para Demetrio, pero éste reservaba la decisión para su hijo Antíoco y para Estratonice e iba prolongando el tiempo a fin de que la gracia fuera de éstos:

Plutarco remite al poema de Safo, 31 L-P para la sintomatología del amor, pero probablemente cita de memoria, pues no coincide estrictamente ni el léxico empleado por ambos ni el orden de los sintomas e incluso introduce algunos efectos que no aparecen en el fragmento de la lesbia como el desmayo, la duda y el estupor (Tịs Demetr. 38.4).

Sobre la veracidad de la anécdota cf. Aguil.Ar, 2004, pp. 428-9.

Apiano (Syr. 59-61) relata el mismo episodio de forma tan semejante que debemos pensar en la posibilidad de que hubiera tomado como fuente a Plutarco. Cf. también Lucian., Syr.D. 17-18.

11

Cf. BIELMAN, 2002, p. 70. 


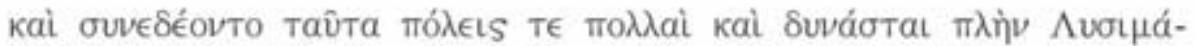

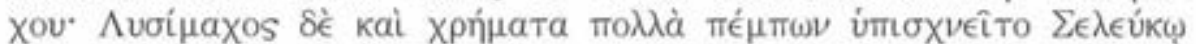

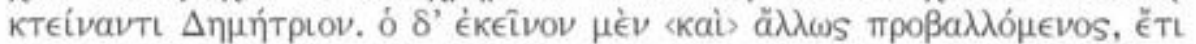

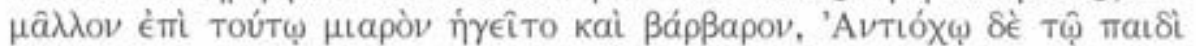

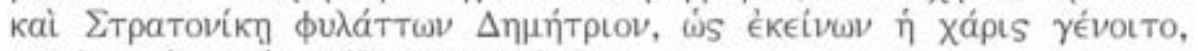

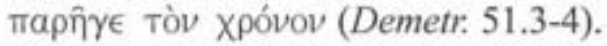

Pero, al parecer, Estratonice nunca llegó o, si lo hizo, no intercedió o no tuvo suficiente fuerza su criterio para ayudar a su padre. Finalmente, al cabo de tres años en aquel encierro Demetrio enfermó y murió a la edad de cincuenta y cuatro años (Demetr. 52.5).

\section{Mujeres de Demetrio}

Según hemos visto al comienzo, Demetrio era inclinado a concertar muchos matrimonios y a estar unido con varias mujeres a la vez. Por este motivo, de entre los reyes, fue el que peor opinión tuvo en relación con esta clase de placeres. Además, era tan poca la estima que profesaba a File y a sus restantes esposas que tenia libremente relaciones con otras muchas heteras y mujeres libres:

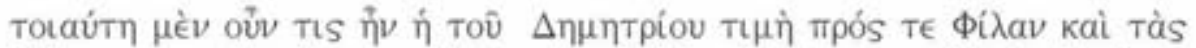

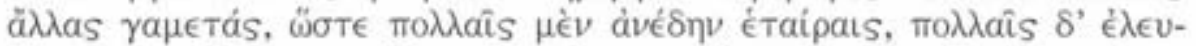

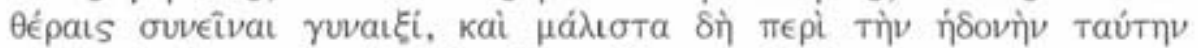

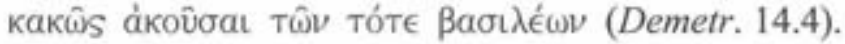

Es fácil percibir en estas líneas una concepción jerárquica respecto al estatus de las compañeras de Demetrio. Ciertamente, en la cúspide se halla File, su mujer por excelencia, quien goza del privilegio de aparecer con nombre propio frente a las

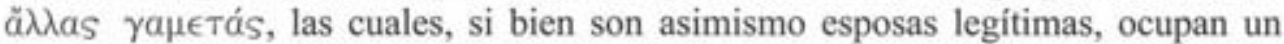
rango secundario para el autor, pues se agrupan en un todo indefinido sin alusión explícita a su personalidad individual. Por otra parte, Demetrio se relaciona con heteras y mujeres libres y Plutarco hace hincapié en que, tanto unas como otras,

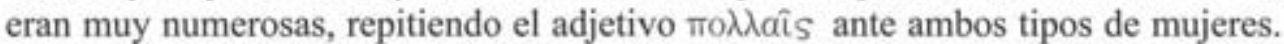
Por tanto, las consortes, que aparecen en una estructura bipartita en orden de relevancia, tienen su contrapartida en las amantes, que también se presentan en dos categorias diferenciadas por su posición social. Pero ésta es una división hecha por Plutarco quien deja entrever su propio criterio respecto de la consideración que estas diversas mujeres merecian. Pasemos a ver qué refiere el queronense de cada una de ellas.

\subsection{File}

File era hija del regente Antípatro, quien supo llevar a cabo una estratégica politica matrimonial con sus descendientes: a Nicea la casó con Pérdicas y, luego, con Lisímaco, a Eurídice con Ptolomeo y a File con Crátero y, muerto éste, con Demetrio. Según Plutarco, entre todas las esposas de Demetrio, File tenía el primer 
lugar, ya fuera por el prestigio de su padre Antípatro, ya por haber estado antes casada con Crátero, quien, de los sucesores de Alejandro, era el que mayor deseo de si había dejado a los macedonios:

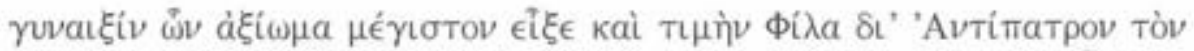

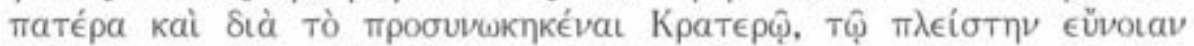

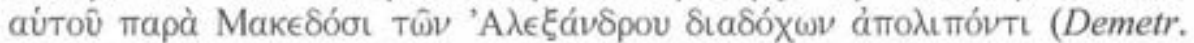
14.2-3).

En efecto, File había sido entregada por su padre a Crátero en el año 322 a. C. e incluso se ha sugerido ${ }^{12}$ en ocasiones que ya había estado por aquel entonces casada con Balacro, un general de Alejandro, opinión basada en que File había pasado ya su primera juventud. Del hijo que File tuvo con Crátero nada dice Plutarco, pero es que se trata ahora de la vida de Demetrio y no es cuestión de detenerse en detalles accesorios.

Así pues, refiere el de Queronea que siendo muy joven Demetrio le persuadió su padre de que tomara a File por esposa pese a ser ella mayor que él en edad. Pero como éste no se mostraba muy complacido con la idea, dicen que Antígono le recitó al oído una máxima de Euripides, según la cual es deber casarse donde está el provecho aunque la naturaleza impulse a otros caminos ${ }^{13}$ :

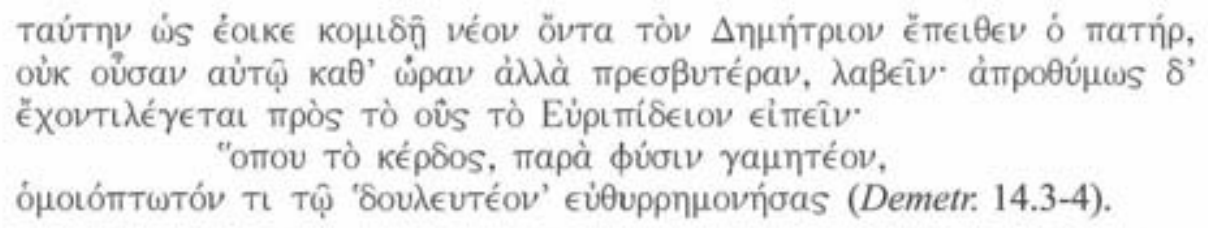

En realidad, Antígono modificó ligeramente el verso original del trágico que

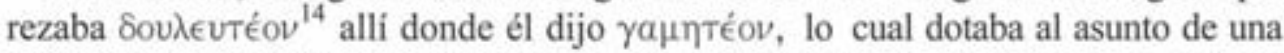
cierta ligereza cómica. La frase debió de persuadir taxativamente a Demetrio, pues su boda con File fue tan apresurada que, cuando le llegó a ésta el cuerpo de Crátero, enviado por Eumenes para su sepultura, ya estaba casada con el joven. Contaba Demetrio entonces con unos dieciocho años, mientras ella andaba en torno a los treinta. Parece que desde aquel momento, como bien observa Macurdy (1932: 61), Demetrio mostró una clara tendencia a enamorarse de mujeres bastante más mayores que él.

Una vez celebrada la boda, File se marchó a Asia y vivió allí hasta pocos años antes de que su marido se convirtiera en rey de Macedonia el año 294 a. C. Lo cierto es que no disfrutaron de una convivencia demasiado intensa porque File se hallaba generalmente al margen de las expediciones militares de su marido. No obstan-

Cf. Plut., Ant. 88.5.

14

Cf. Eur., Phoen. 395. 
te, la comunicación entre ellos se mantenía viva a pesar de la distancia y en momentos puntuales tenían ocasión de encontrarse. Testimonia Plutarco cómo uno de los envios de File a su esposo, que contenía cartas, alfombras y ropa fue apresado por los rodios, quienes lo enviaron a Ptolomeo. Se compara en este punto el comportamiento de los rodios con el de los atenienses cuando, durante la guerra con Filipo, cogieron a unos portadores de cartas y, pese a leerlas todas, no sólo no abrieron la de Olimpia, sino que, sellada como estaba, la remitieron a Filipo:

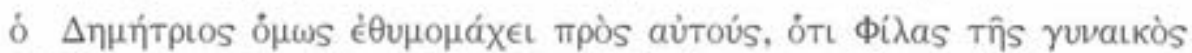

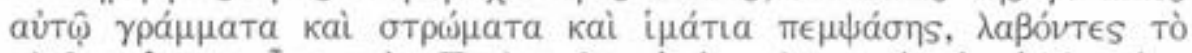

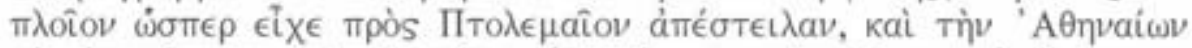

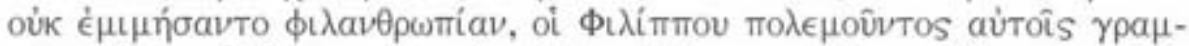

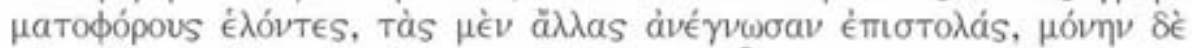

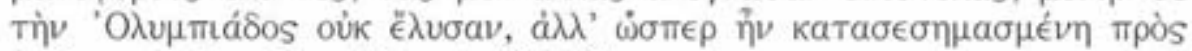

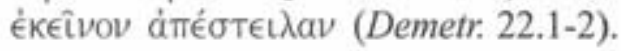

Es éste un ejemplo de cómo Demetrio se tomaba en ocasiones la guerra a modo de venganza personal, pues, al decir de Plutarco, les hacía la guerra a los rodios con obstinación porque habian apresado el barco en el que viajaba el envío de su esposa. También Diodoro Sículo, testimonia el asunto afirmando que en este momento File vivía en Cilicia, desde donde partieron los regalos para su esposo:

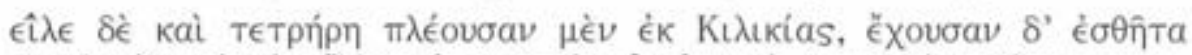

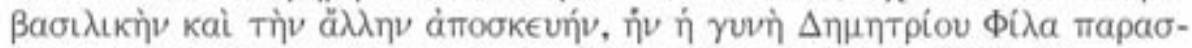

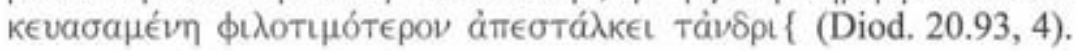

Por tanto, a pesar de la distancia, la hija de Antípatro se encontró en distintos puntos y con su marido. De hecho, también cuando Demetrio se dirigía a Siria a fin de entregar a su hija Estratonice como esposa a Seleuco, se le reunió su mujer File:

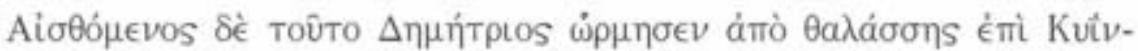

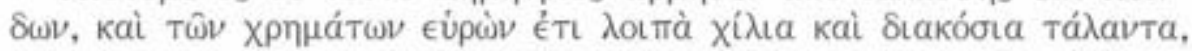

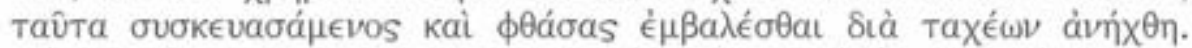

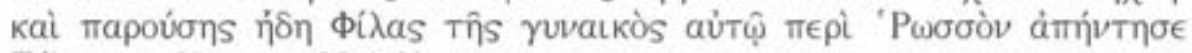

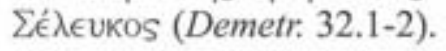

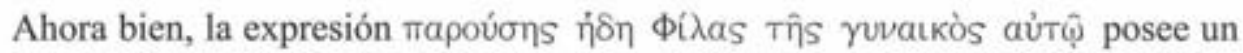
carácter resultativo, aunque no aclara el momento exacto de la llegada de File a presencia de Demetrio. Pero si el testimonio de Diodoro, según el cual ella habitaba en Cilicia, es correcto, es verosímil pensar que se unió a la expedición cuando su esposo navegaba con Estratonice camino hacia Siria y, tal y como relata Plutarco, se vió en la necesidad de hacer un alto en la Cilicia, donde dominaba Plistarco. Éste entendió el acercamiento como una afrenta, porque esta provincia le había sido entregada tras la batalla con Antigono como un don especial y se dispuso entonces a quejarse a Seleuco, hecho que tendría importantes consecuencias (Demetr. 31.7). 
A la vista de los datos, después de la boda entre Seleuco y Estratonice, Demetrio recobró la Cilicia y envió a su mujer File a la corte de Casandro, su hermano, ${ }^{15}$ con el objeto de desvanecer las acusaciones de Plistarco. Vemos así, cómo las mujeres de los dirigentes participaron activamente del entramado político, aprovechando para ello sus vínculos familiares:

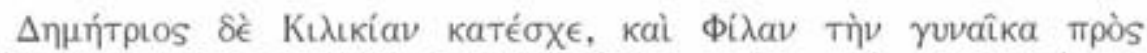

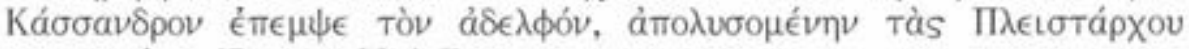
катпүоріаs (Demetr. 32.4-5).

Es ésta la última mención a File después de la boda de su hija Estratronice. No parece que volviera a reunirse con su esposo y permaneció probablemente en Macedonia, donde se sabía apreciada.

Cuando Demetrio consiguió el reino de Macedonia después de matar a Alejandro, el hijo de Casandro, no halló ninguna objeción en tanto que, por una parte, los macedonios detestaban lo mal que Casandro se había portado con Alejandro Magno después de su muerte y, por otra, si algún recuerdo quedaba del antiguo Antípatro, lo disfrutaba Demetrio por convivir con File y tener de ésta un hijo, sucesor del poder, que ya era un muchacho y militaba con su padre:

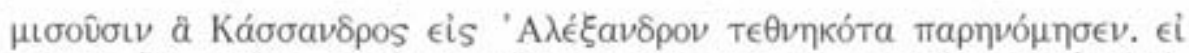

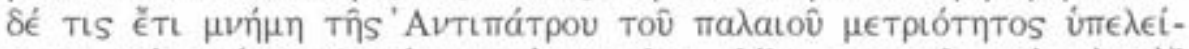

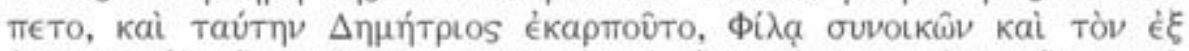

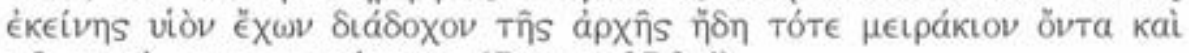

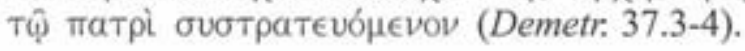

A fin de ofrecer una visión global de los vínculos que unían a los personajes comentados, ofrecemos a continuación un árbol genealógico de la familia de File:

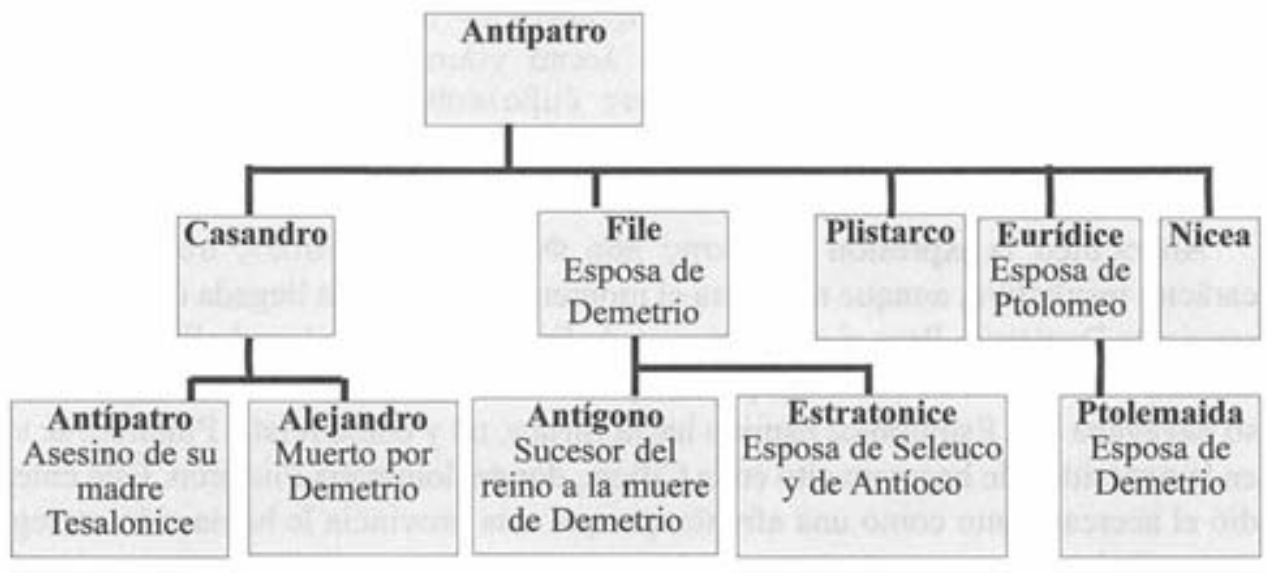

15 No olvidemos que File, Casandro y Plistarco eran hermanos entre si. Cf. Plut., Demetr. 31. 
Probablemente, las mujeres de Demetrio sentian su matrimonio como una cuestión de estatus, más que de amor entendido a la moderna, y es tal vez por ello por lo que consideraron la caida del esposo como el fin de su estabilidad. Así, cuando se coligaron Seleuco, Ptolomeo y Lisímaco contra Demetrio, éste se vió destituido de sus asuntos y huyó a Casandrea. Su mujer File, afectada, no soportó verlo convertido en el más infortunado de los reyes, de nuevo un hombre común y fugitivo. $\mathrm{Y}$, desistiendo de toda esperanza y aborreciendo su fortuna, más firme en los males que en los bienes, bebió un veneno y murió ${ }^{16}$ :

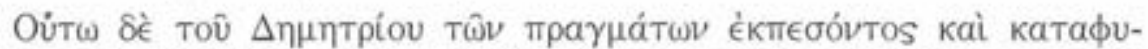

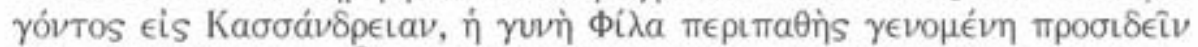

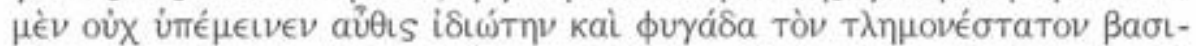

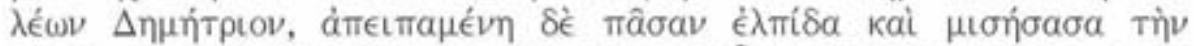

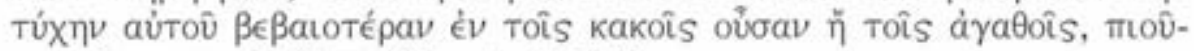

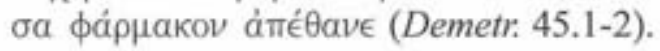

Si File amó o no a su esposo no es una cuestión determinante para la historia de Macedonia. Lo que sí resulta significativo es el hecho de que su actitud siempre fue tolerante respecto a los deslices de su marido y no incurrió nunca en censuras, ataques o agravios ni consideró jamás en peligro su estatus ni su autoridad hasta el final. Los amores de Demetrio no parecen haber desatado sus celos ni sus ansias de poder: siempre en el lugar que le correspondía, dedicada a sus asuntos, se limitó a vivir una vida tranquila, gozando del apoyo y la buena opinión de los macedonios. Tal vez fuera esta faceta parte de la capacidad estratégica desarrollada a lo largo de su educación, dado que, según informa Diodoro (XIX 59, 5), desde jovencita era con frecuencia consultada por su padre en cuestiones relativas al gobierno. Fue la única mujer de Demetrio hasta que en el año 307 a. C. el monarca se casó con la ateniense Euridice, pero este hecho no provocó la ira de File, quien no otorgó más consideración a este casamiento que a los amoríos de su marido con las heteras.

Finalmente, si File hubiera sabido que su hijo Antigono sería el siguiente rey de Macedonia, probablemente no se habría abandonado a la desesperación y el destino de sus últimos momentos habria sido otro bien distinto. Por consiguiente, podemos afirmar que estas mujeres como File, sometidas a muertes obligadas -por mandato ajeno o por imperativo moral propio-, fueron, en palabras de la profesora Aguilar ${ }^{17}$, víctimas de su alta alcurnia.

Es significativo que el suicidio femenino en virtud de una causa mayor sea una de las virtudes ensalzadas frecuentemente por Plutarco. Cf. Plut., De Mul. Virt. 244 y $257 \mathrm{~F}-258 \mathrm{C}$, asi como Gallé Ceundo, 2001, p. 508.

17

Cf. Agullar, 2006, p. 34. 


\subsection{Euridice}

De esta mujer poca información ofrece Plutarco: mientras Demetrio descansaba en Atenas, se casó con la viuda Eurídice, descendiente del antiguo Milcíades. Ésta habia regresado a Atenas tras la muerte de su marido Ofeltas, príncipe de Cirene y los atenienses vieron esta unión como un honor dispensado a su ciudad:

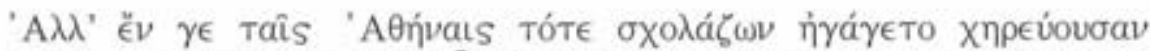

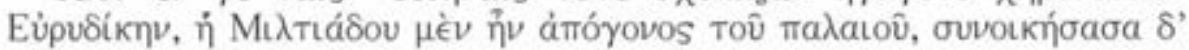

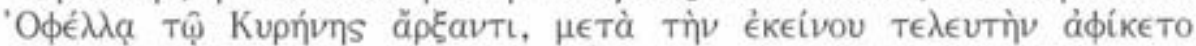

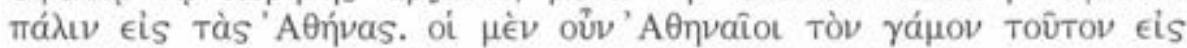

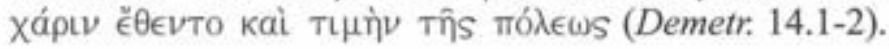

Eurídice le dio un hijo a Demetrio llamado Corrabo. Cuatro años después de su boda con ella, Demetrio tomó por esposa a Deidamía en el año 303 a. C.

\subsection{Deidamía}

De acuerdo con los informes del queronense, una vez que Demetrio pasó al Peloponeso y rescató Argos, se casó con Deidamía, hija de Eacida, rey de los Molosos y hermana de Pirro ${ }^{18}$, mientras presidia alli los combates y las fiestas en honor a Hera ${ }^{19}$ :

ย̇v "A

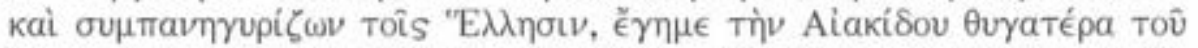

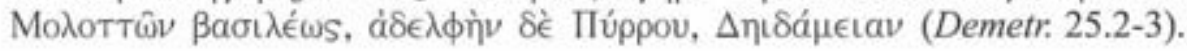

No está claro dónde se hallaba File en este momento. Tal vez, como señala Macurdy (1932: 63), habia sido enviada por Demetrio a negociar una tregua con Casandro que le permitiera atender la llamada de su padre Antigono antes de la fatidica batalla de Ipsos. Muerto éste y vencido por todos los demás reyes coligados contra ellos, Demetrio se dirigió desde Éfeso a Atenas porque alli había dejado naves, dinero y a su mujer Deidamía y pensaba hallar refugio en el amor de los atenienses. Sin embargo, le salieron al encuentro embajadores de Atenas para decirle que no entrase en su ciudad y a Deidamia la condujeron a Mégara con el honor y el acompañamiento conveniente, ante lo cual Demetrio montó en cólera:

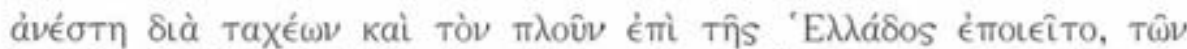

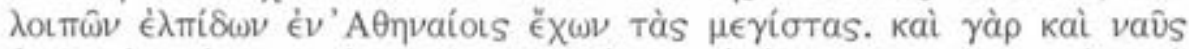

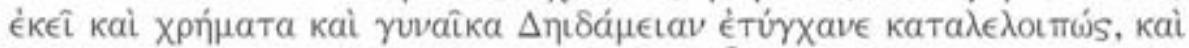

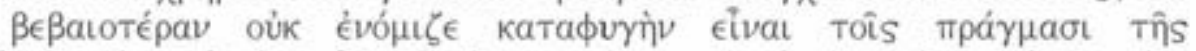

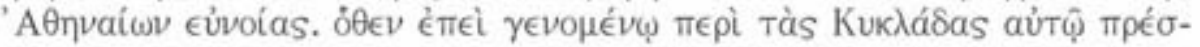

Deidamía era aún joven, pese a haber estado ya casada anteriormente con Alejandro, el hijo de Roxana. Cf. Plut., Pyrrh. 4.3. 


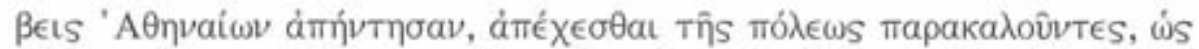

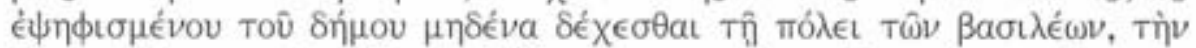

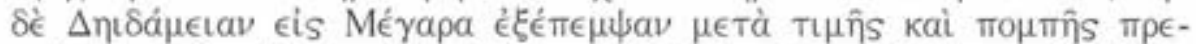

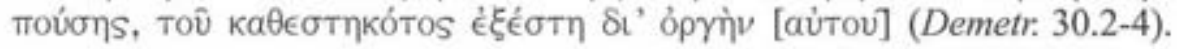

Fue probablemente durante este periodo, en que Demetrio dejó a Deidamía en Atenas o una vez que la hubo enviado a Corinto, cuando mandó llamar a File para que le ayudara en los preparativos de la boda de su hija Estratonice. Al menos en esto tuvo Demetrio la delicadeza de evitar que sus mujeres se encontrasen: a su vez, mientras enviaba a File a desvanecer las acusaciones de Plistarco, Deidamía llegaba desde Grecia para reunirse con él. Desgraciadamente, no mucho tiempo después, en torno al año 299 a. C., la hermana de Pirro murió de una enfermedad ${ }^{20}$ :

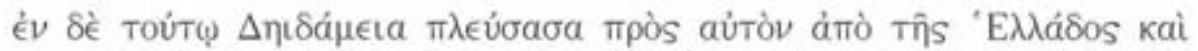

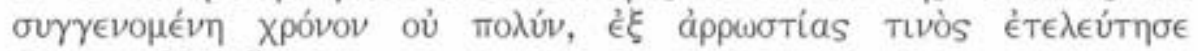
(Demetr: 32.5-6).

Este matrimonio, del que nació un hijo llamado Alejandro, formó parte de una importante política de alianza, pues unió a Demetrio con el joven y poderoso reino de Epiro, constituyendo así un paso importante hacia la consecución de Macedonia.

\subsection{Ptolemaida}

Ptolemaida es la hija de Ptolomeo I Soter y Euridice, hermana de File y, por tanto, sobrina de esta última. Aunque Plutarco no lo menciona, tuvo de Demetrio un hijo que fue llamado Demetrio el Hermoso, padre a su vez de Antígono III de Macedonia apodado Dosón. Tras la muerte de Deidamía, por mediación de Seleuco trabó Demetrio amistad con Ptolomeo y acordó que tomaría a Ptolemaida, su hija, por esposa:

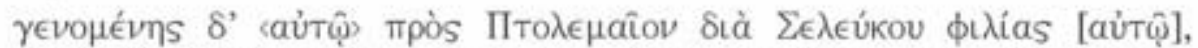

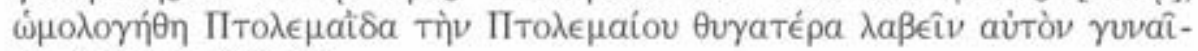
ка (Demetr: 32.6-7).

Sin embargo, no fue hasta después de la muerte de File cuando Demetrio se casó con esta joven en el año 286 a. $C^{21}$, unos trece años después de su compromiso. En efecto, relata nuestro autor que, estando Demetrio en guerra con los demás reyes, navegó en dirección a Asia a fin de alejar a Caria y Lidia de Lisímaco. Pero en Mileto lo recibió la hermana de File, Eurídice, trayéndole, de las hijas de Ptolomeo, a Ptolemaida que le estaba prometida en matrimonio por medio de Seleuco. Se casó con ella, tomándola de la mano de su madre, e inmediatamente después de la boda

\footnotetext{
${ }^{20}$ Cf. Plut., Pyrrh. 7.3.

${ }^{21}$ Cf. MACurdy, 1932, p. 56.
} 
arremetió contra las ciudades. De éstas, muchas se le sometieron voluntariamente y a otras tantas las redujo por la fuerza:

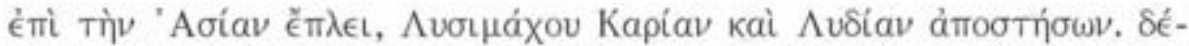

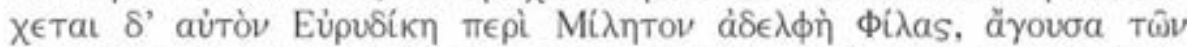

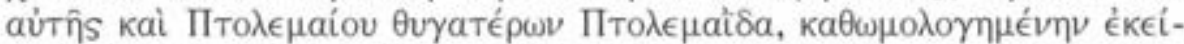

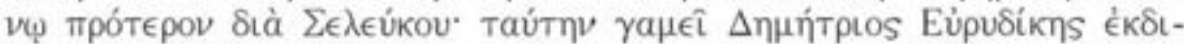

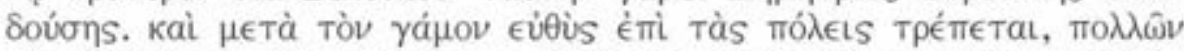

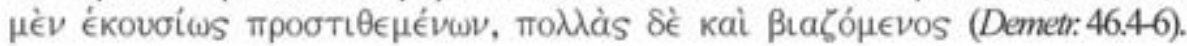

Nada más añade Plutarco de este enlace, a no ser que Ptolemaida le dio un hijo llamado Demetrio que se quedó reinando en Cirene (Demetr. LIII). Su personalidad queda pues subyugada a la voluntad de su madre y a los dictados de su esposo sin que tengamos la oportunidad de oír los ecos de su propia voz entre los testimonios del queronense.

\section{Amantes de Demetrio}

\subsection{Cratesípolis}

Poco es lo que sabemos de esta mujer y Plutarco la menciona tan sólo una vez en el conjunto de su obra con ocasión de ilustrar la debilidad de Demetrio por la belleza femenina. Tenemos conocimiento ${ }^{22}$ de sus dotes de mando y de su capacidad estratégica al frente de importantes ciudades griegas, así como de una armada de mercenarios. ${ }^{23}$ Es posible que aspirara a convertirse en esposa de Ptolomeo I Soter cuando puso Corinto en sus manos, pero, por aquel entonces, Berenice ya estaba embarazada y ocupó el trono en su lugar. Lo cierto es que al final se casó con Alejandro, el hijo de Poliperconte, y habitaba en Patras, aunque no debía de ser muy feliz, pues andaba seduciendo a varones apuestos como Demetrio. Asi, refiere el queronense que, cuando Antigono y su hijo concibieron la idea de libertar a toda Grecia esclavizada por Casandro y Ptolomeo, se lo comunicaron a los atenienses, quienes los recibieron favorablemente. Tras ello, Demetrio se dirigió por mar hacia Mégara, guarnecida por Casandro, donde se enteró de que la bella Cratesípolis "de

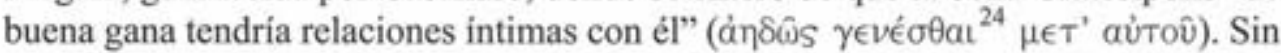
más dilación, dejó el ejército en tierras megarenses y partió llevando consigo unos hombres bien dispuestos. También de éstos se apartó y acampó aparte a fin de ocultar que la mujer se reunía con él. No obstante, algunos de sus enemigos se percataron de ello. Él, temeroso al verse perseguido, cogió una clamiducha barata y consiguió escapar a la carrera, a punto de caer en la más vergonzosa cautividad:

No debía de ser rara la presencia de reinas a la cabeza de un ejército a juzgar por la existencia de documentos que lo testimonian. Cf. BIELMAN, 2002, pp. 282-3. 


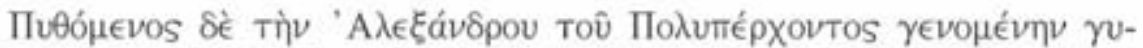

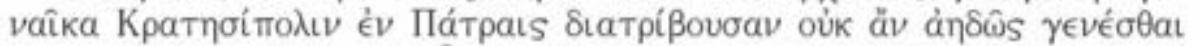

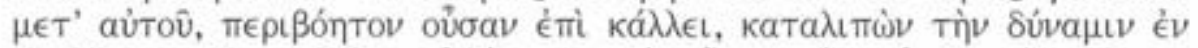

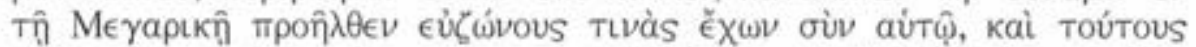

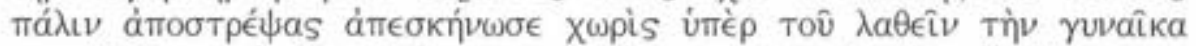

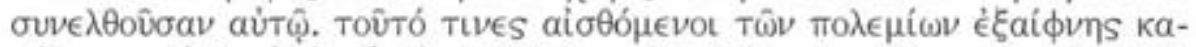

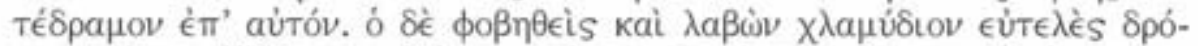

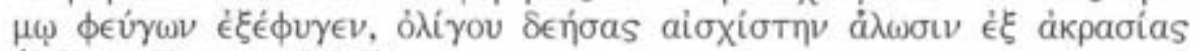

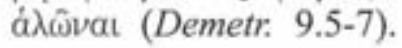

De Cratesípolis nada más sabemos. Plutarco concluye la anécdota afirmando

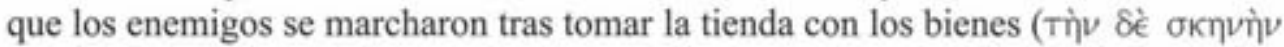

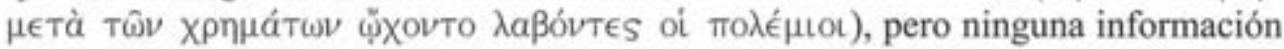
añade acerca del destino de la joven. Su presencia se halla, pues, subordinada al protagonismo de Demetrio.

\subsection{Lamia}

Éste es, sin duda, el personaje femenino de más relevancia en la vida del monarca, a juzgar por los comentarios de Plutarco. Era, según el de Queronea, muy celebrada al principio por sus dotes como flautista y luego famosa en virtud de sus asuntos amorosos. Pese a haber entrado ya en el declive de su belleza, logró retener a Demetrio hasta el punto de que de ella sola era amante, de las demás amado ${ }^{25}$ :

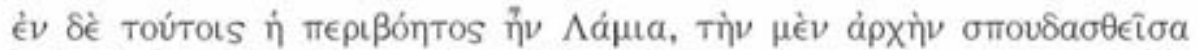

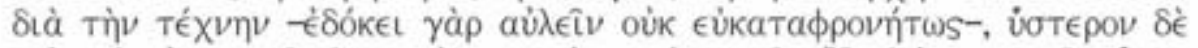

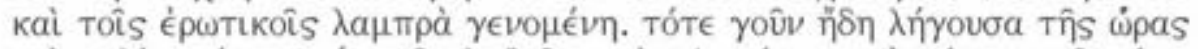

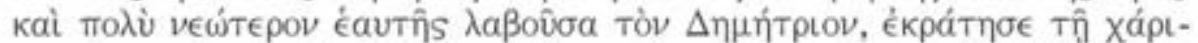

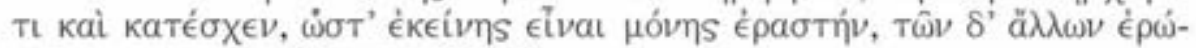

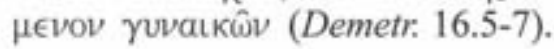

Y es que el poder de Lamia ${ }^{26}$ sobre Demetrio era tal que, a la vuelta de un viaje,

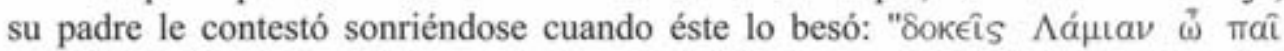
катафı $\lambda \in \hat{v} v "$ ("Parece, hijo, que besas a Lamia", Demetr: 19.6). Así pues, de todos conocido era su romance con ella. Cuenta Plutarco que, en una ocasión, Lisímaco estaba molesto porque Demetrio le llamaba "tesorero", ya que los encargados de tales tareas eran, en su mayoría, eunucos. Era de sus enemigos el que más le odiaba y, a fin de censurarle por sus amores con Lamia, dijo que ahora, por vez primera, se había visto una prostituta salida de la escena trágica. Ante estas palabras, Demetrio contestó que su prostituta era más prudente ${ }^{27}$ que la Penélope de aquél:

25

26

27

Cf. Plut., Ant. 90.2.

No es infrecuente hallar en Plutarco el reflejo de varones dominados por sus amantes. Así sucede con Mitridates, subyugado por los encantos de su concubina Hipsicratía en Pomp. 32.

Para el sentido de ouфрovétépav debemos remitimos a la definición que ofrece el propio Plutarco de owфponoúvm en De Virt. Mor. 445b. 


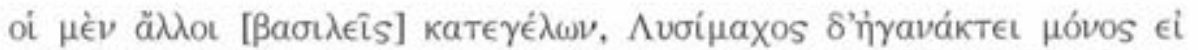

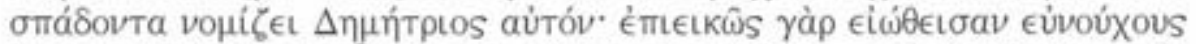

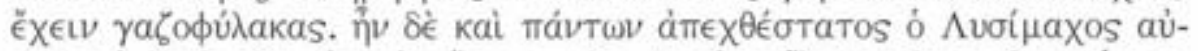

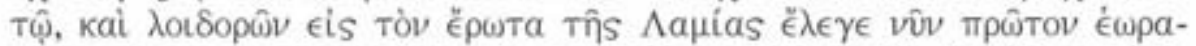

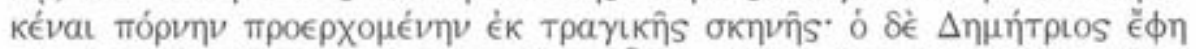

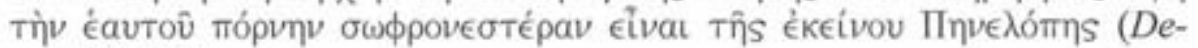
metr: 25.8-9).

Esta Penélope no era otra que Arsínoe II, esposa por aquel entonces de Lisímaco, la misma que se enamoró de Agatocles, hijo de su propio marido con la hija de Antípatro, Nicea, al que posteriormente envenenó ${ }^{28}$.

La fuerza con la que Lamia invadía el pensamiento de Demetrio era inmensa. ${ }^{29}$ En efecto, de las muchas injusticias cometidas durante su estancia en Atenas, la que más entristeció a los atenienses fue que cuando pagaron los 250 talentos exigidos por Demetrio, éste ordenó que se entregara todo a Lamia y a las otras heteras que tenía consigo para jabón, pues sintieron más la vergüenza que la multa. No obstante, algunos dicen que no sucedió esto con los atenienses, sino con los tesalios:

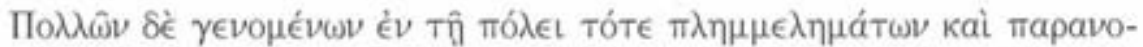

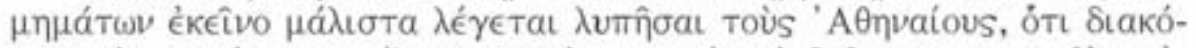

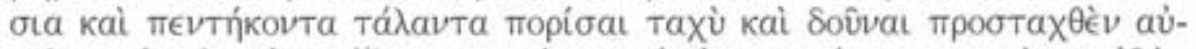

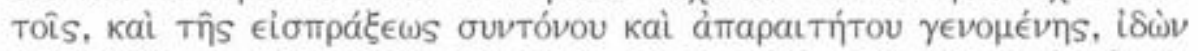

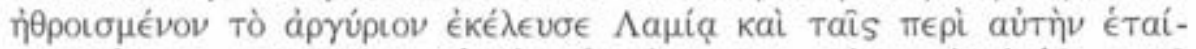

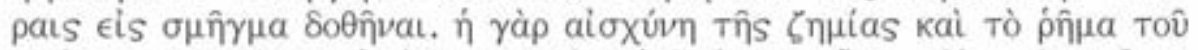

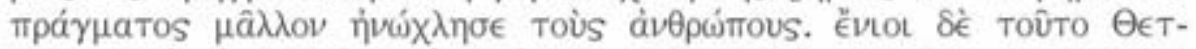

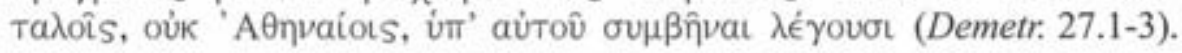

Lamia gozaba, además, de una cierta autoridad ${ }^{30}$, según se desprende de algunos datos recogidos por Plutarco. Por ejemplo, cuando una vez quiso preparar un banquete por sí misma, pidió para ello dinero a muchos y el festín fue tan famoso por su suntuosidad que Linceo de Samos escribió sobre él. Por esto un poeta cómico llamó a Lamia con el nombre de la máquina destructora de ciudades ideada por Demetrio: Helépolis. ${ }^{31}$ Y Demócares de Solos llamaba a Demetrio Cuento, porque

Cf. MACurdy, 1932, p. 113.

Sobre el poder de las heteras sobre los hombres a través del ẹ̌ GonzAlez Almenara, 2001, pp. 380-1.

En general, se observa en nuestro autor una tendencia a describir las esposas sumisas frente a las cortesanas dotadas de un carácter fuerte. Cf. Plut., Alex. 38.2-4.

Lamia recibia este sobrenombre del mismo modo que Demetrio era llamado Poliorcetes. El paralelismo se halla en consonancia con la opinión de Plutarco de que tanto hombres como mujeres

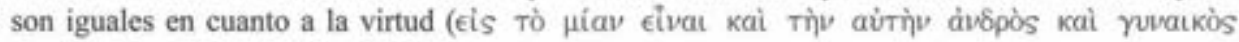
áp€тìv, Plut., De Mul.Virt. 243a). 
decía que tenía, como los cuentos, su Lamia ${ }^{32}$ :

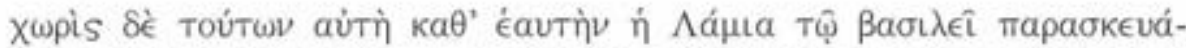

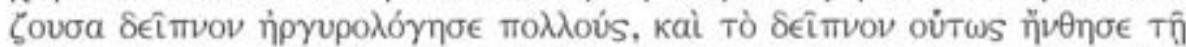

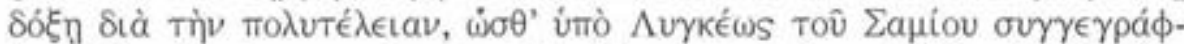

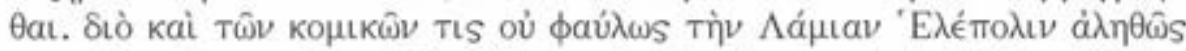

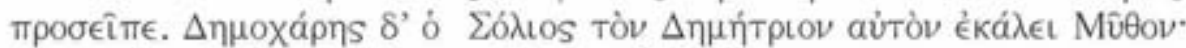

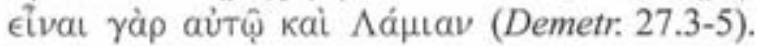

En efecto, según el Sch. a Ar., Pax 758, Lamia era una princesa libia amada por Zeus que padeció las iras de Hera. Como castigo, ésta hizo perecer a todos sus hijos y la privó del sueño, de forma que la joven, enloquecida, se convirtió en un ser espantoso que robaba y mataba a los niños, envidiosa de las madres felices. Como compensación, Zeus le concedió la posibilidad de arrancarse los ojos por intervalos a fin de descansar de su desgracia. ${ }^{33}$ Contrariamente, la Lamia de Demetrio no sólo despertaba los celos y la envidia entre las mujeres legitimas de su amante, sino también entre sus amigos, pues era amada y feliz. Cuenta Plutarco otra anécdota según la cual llegaron unos embajadores de parte de Demetrio a Lisímaco, a quienes éste, en un momento de ocio, mostró en los muslos y en los brazos cicatrices profundas de las uñas de un león y les narró la lucha acaecida cuando fue encerrado con aquella fiera por el rey Alejandro. Ellos, sonriéndose, le dijeron que también su rey llevaba en el cuello mordiscos de una terrible fiera, Lamia:

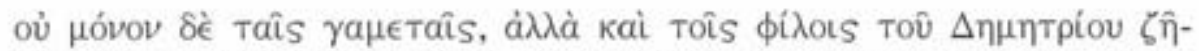

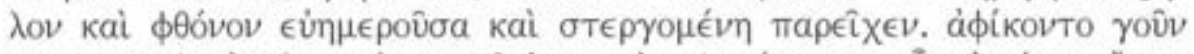

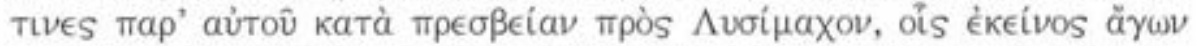

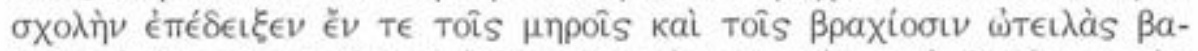

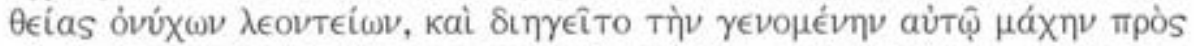

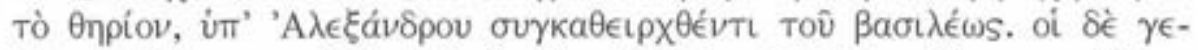

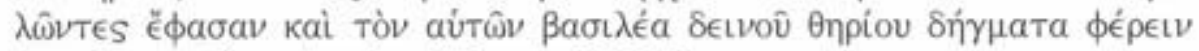

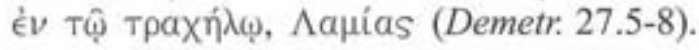

Era admirable, al decir de Plutarco, que después de haber tenido reparos al principio para casarse con File por la edad, se hubiera dejado vencer por Lamia y la hubiera amado durante tanto tiempo, pasada ya su flor. Por eso, cuando Demetrio le preguntó a Demo, llamada también Manía, qué le parecía la flautista, refiriéndose a Lamia, contestó: "Vieja, mi rey". Y en otra ocasión, una vez servidos los postres en la mesa le dijo el mismo Demetrio: "¿Ves qué de cosas me envía Lamia?, Muchas más te enviaría mi madre-le respondió (Demo)-si quisieras dormir con ella": 


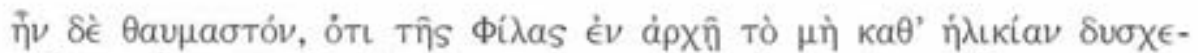

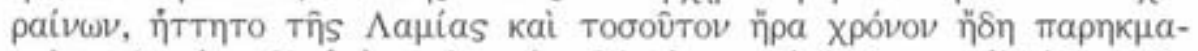

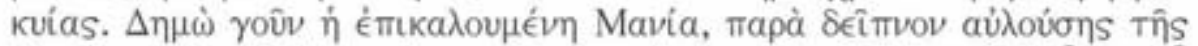

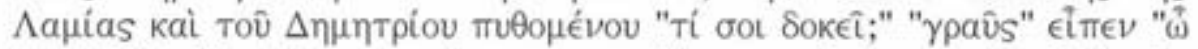

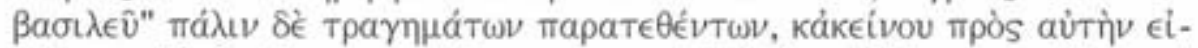

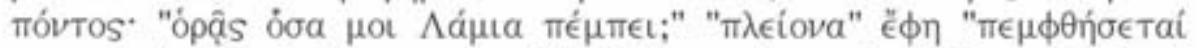

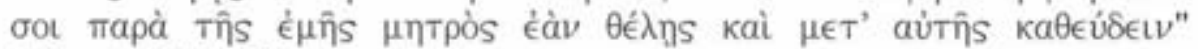
(Demetr. 27.8-11).

Se conserva finalmente una anécdota que ilustra el sentido de justicia y la sensate $^{34}$ de esta mujer, virtudes a las cuales aludía antes el propio Demetrio al compararla con la Penélope de Lisímaco. Se trata de la oposición de Lamia a la llamada sentencia de Bocoris. Resulta que estando uno enamorado en Egipto de la hetera Tonis le había ofrecido mucho dinero, pero luego le pareció que se unia a ella en sueños y desapareció su deseo. Tonis intentó un proceso contra él a fin de cobrar el salario acordado. Finalmente, Bocoris mandó que el hombre trajera el dinero prometido y que con la mano lo sacudiera aquí y allá y la cortesana obtuviera la sombra, en la idea de que la opinión era la sombra de la verdad. Pero a Lamia le pareció que esta sentencia no era justa, porque la sombra no satisfizo en la cortesana el deseo de dinero, del mismo modo que el sueño habia hecho cesar el amor en el muchacho:

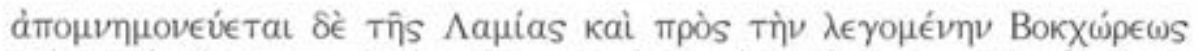
крiб

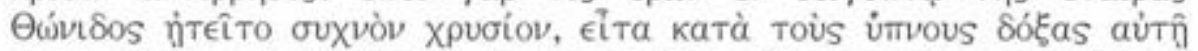

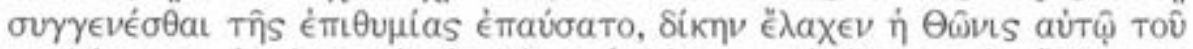

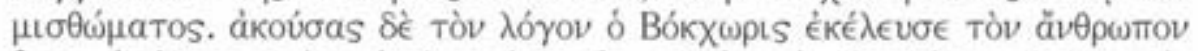

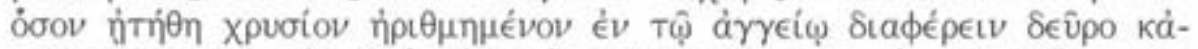

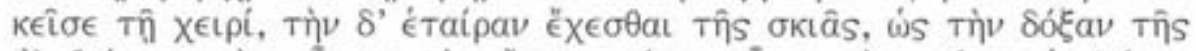

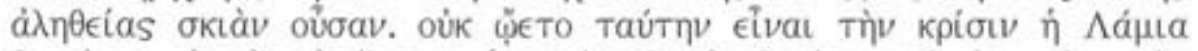

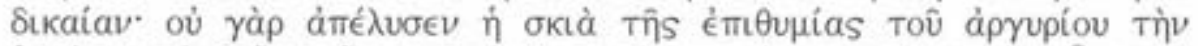

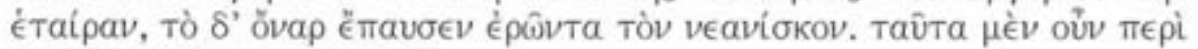
Aapias (Demetr: 27.11-14).

De la resolución definitiva nada se dice pero suponemos que se cumpliría la sentencia de Lamia y no la de Bocoris.

\section{Otras mujeres}

\subsection{Tesalonice}

Tesalonice nació entre los años 346 y 340 a. C., hija de Filipo y una mujer tesalia llamada Nicesípolis, pero se crió con su madrastra Olimpia al morir su madre

En este aspecto, guarda ciertas semejanzas con la Aspasia de Plut., Per. XXIV. Cf. BLomQuist, 1997 , pp. 77-8. 
cuando contaba con tan sólo tres semanas. Parece haber tenido una naturaleza más blanda que las demás hijas de Filipo, de madres ilirias o epirotas, y no tenemos noticia de ella actuando en la vida pública o en la guerra, lo cual contrasta con los móviles de su asesinato, al parecer por motivos políticos ${ }^{35}$. Casandro la tomó por esposa cuando ésta tenía unos treinta años, convirtiéndose así en un miembro de la familia real y acercándose de forma notoria al poder. Como incluso los hijos ilegítimos tenían prioridad sobre la línea de descendencia femenina en la herencia del reino ${ }^{36}$ y Tesalonice debió de ser considerada hija legitima de Filipo, si bien no de su principal esposa ${ }^{37}$, Casandro fue declarado heredero y rey de Macedonia el año 305 a. C. y Tesalonice su reina. La ciudad que Casandro construyó para ella conserva todavía su nombre, Tesalónica o Saloniki.

El personaje de Tesalonice aparece en esta obra en calidad de madre, como ejemplo de los crímenes familiares que se producían sin cuento en las cortes helenísticas a causa del poder. Poco después de la muerte de Casandro acaecida en el 298 a. C., su hijo primogénito también falleció y Tesalonice se convirtió en regente, de modo que los dos hijos restantes entraron en discordia por el trono. Siendo así, uno de ellos, Antípatro, tal vez por celos de su hermano que era el favorito de su madre, dio muerte a ésta. Como consecuencia, el otro, Alejandro, llamó en auxilio del Epiro a Pirro y del Peloponeso a Demetrio:

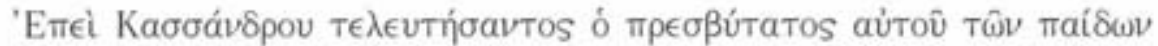

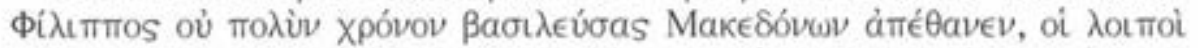

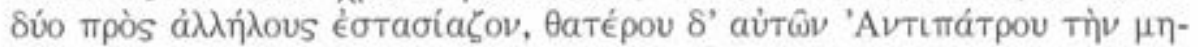

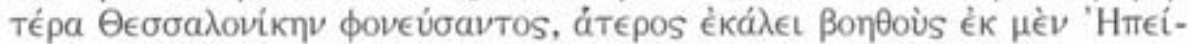

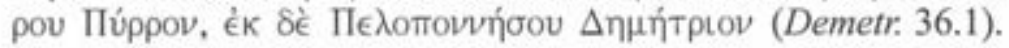

Pero Pirro tomó como recompensa por el socorro gran parte de Macedonia y, al llegar Demetrio, Alejandro sintió desconfianza y quiso ponerle una trampa. Demetrio se percató y dió finalmente muerte a Alejandro en un banquete ${ }^{38}$. Entonces, los macedonios, que aborrecían a Antípatro por haber asesinado a su madre y no disponían de alternativa alguna para el trono, lo proclamaron rey:

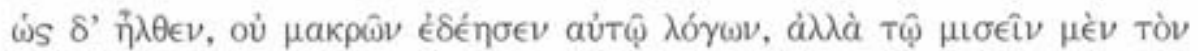

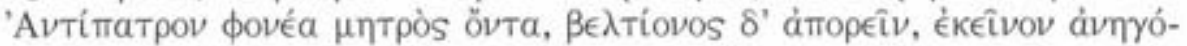

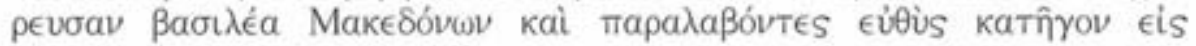

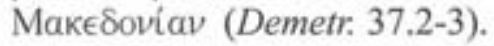

Cf. MACurdy, 1932, p. 52.

Asi, sólo una vez extinguida la linea masculina, fue heredera Cleopatra, hermana de Alejandro. Cf. Diod., XX 37.4.

MACURDY, 1932, p. 53 , n. 132.

Plut., Demetr. 36; Pyrrh. 6 y Pausan., 9.7,3. 
De estas palabras se desprende que, si bien los crímenes familiares eran sumamente frecuentes, estaban muy mal vistos y constituian un motivo de desconfianza, pues quien tenía el valor de asesinar a su propia madre sería capaz de cometer cualquier clase de atrocidad con sus súbditos. En consecuencia, el matricida se refugió con su suegro Lisimaco en Tracia y murió posteriormente por orden del mismo, aunque Diodoro (21.7) afirma que Demetrio mató a Antípatro porque no deseaba compartir el reino con él.

Con la desaparición de Tesalonice y sus hijos, la línea de Filipo II -en la que todos, a excepción de Alejandro Magno y Filipo, el hijo mayor de Tesalonice y Casandro, murieron con violencia- llegó a su fin.

\subsection{Filacio}

Filacio es la amiga de Estratocles, el mismo que propuso que los enviados en calidad de embajadores a Antigono y Demetrio se llamaran Teoros, como los que conducen las víctimas a Delfos y Olimpia en las fiestas de Grecia. Pues bien, a fin de ejemplificar la insolencia de este personaje, relata Plutarco la anécdota que sucedió cuando un día Filacio le compró sesos y cuellos en la plaza con la mejor intención de ofrecérselos. Pero él, en todo insolente, le dijo: "¡Vaya, me has comprado aquellas cosas con que nosotros, los que gobernamos al pueblo, jugamos a la pelota!":

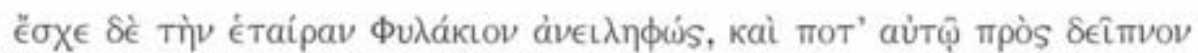
'̇́ à

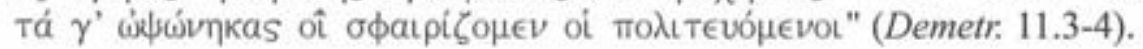

Queda así contrapuesta, por tanto, la falta de respeto y la insolencia de este hombre a la buena voluntad y el cariño de su compañera.

\subsection{Una anciana}

Una intervención anecdótica de un personaje anónimo hace reflexionar a Demetrio acerca de su propia actitud con respecto a sus súbditos. Cuenta Plutarco cómo una mujer anciana le salió al encuentro y le pidió varias veces que la escuchase. Pero él le respondió que no tenía tiempo y ella le dijo en voz alta: "Pues no reines". Fuertemente impresionado por esto, regresó a casa y, tras hacer todas sus tareas, se dedicó, empezando por aquella anciana, a entrevistarse con los que querían durante muchos días. Así aprendió Demetrio la lección de que nada conviene tanto a un rey como el hacer justicia:

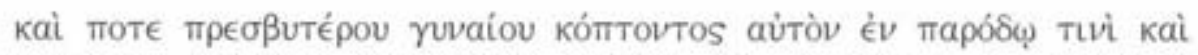

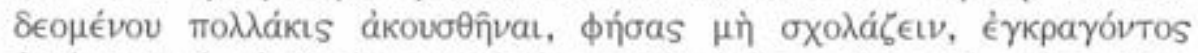

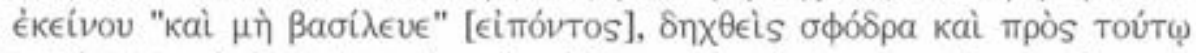

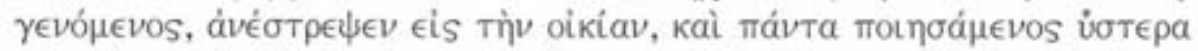

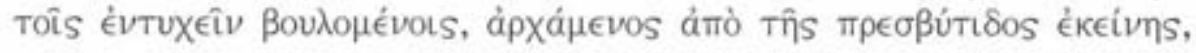




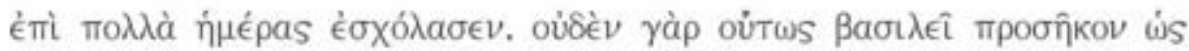

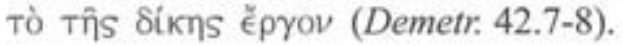

No parece casual el hecho de que sea precisamente una anciana quien logre transmitir unos valores y haga reflexionar al monarca sobre su proceder. Es ya un tópico literario el encuentro más o menos espontáneo de los protagonistas con mujeres mayores que actúan como consejeras, ya sean diosas disfrazadas de ancianas $^{39}$ o mujeres de a pie investidas, gracias a la experiencia, de sabiduria popular ${ }^{40}$.

\subsection{Atenea}

A fin de dar conclusión al análisis de los valores y virtudes de las mujeres en la Vida de Demetrio, hemos de hacer referencia a la relación del monarca con la que él llamaba su hermana mayor, esto es, la diosa Atenea. En efecto, la estancia de Demetrio en Atenas y su relación con el género femenino muestra una moral licenciosa y disoluta, pronta a la satisfacción de los placeres y desconsiderada con los hombres y los dioses. El hecho es que los atenienses, agradecidos a causa de la ayuda prestada por Demetrio, le ofrecieron el Partenón como alojamiento. Sin embargo, éste se comportó de forma tan insolente con los jóvenes libres y las mujeres ciudadanas que parecía que limpiaba el lugar cuando se abandonaba al libertinaje con las rameras Crisis, Lamia, Demo y Anticira:

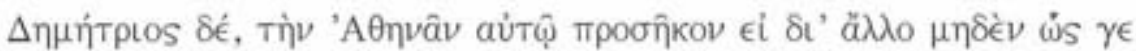

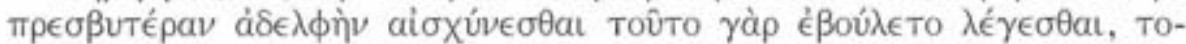

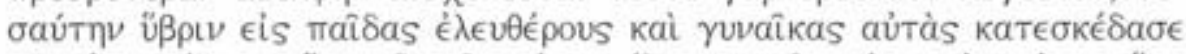

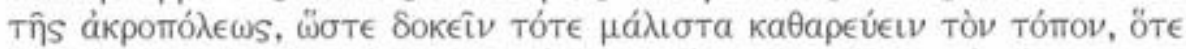

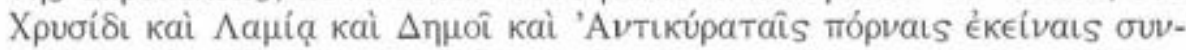
aкодабтаivot (Demetr: 24.1-2).

En definitiva, su conducta no resultó en modo alguno respetuosa con un lugar sagrado y protegido por una diosa sensata y virginal como Atenea. Esta anécdota resume, en cierta manera, los valores y virtudes de Demetrio con respecto a las mujeres, dado que con su actitud arrasadora poco nos ha dejado ver de los auténticos valores y virtudes de las mujeres que lo rodearon.

\section{Conclusiones}

A modo de resumen, podemos afirmar que la mayoría de las mujeres de la Vida de Demetrio pertenecen al ámbito familiar del monarca (su madre Estratonice, su hija homónima, sus esposas File, Eurídice, Deidamía y Ptolemaida) o a su círculo de amores (Cratesípolis, Lamia y otras heteras), si bien aparecen otras a fin de ilus- 
trar ciertos valores morales por su presencia o por su ausencia, como es el caso de Tesalonice, Filacio o la anciana anónima. De acuerdo con lo visto, debemos concluir que estas mujeres no adquieren, en términos generales, un protagonismo ni una relevancia excepcional por sí mismas, sino que vienen a destacar, en realidad, los valores y virtudes -o defectos, según los casos- de los personajes que las rodean. Así, por ejemplo, el cariño que mostraba Demetrio hacia su madre sirve para poner de relieve su virtud en honrar a sus progenitores y el cautiverio de Estratonice con sus nietos muestra una ejemplar unidad familiar; la muerte de Tesalonice señala el límite de crueldad al que puede llegar el hombre motivado por el ansia de poder; Cratesípolis ilustra hasta qué punto es capaz de arriesgarse Demetrio con tal de conseguir los amores de una bella dama; su hija Estratonice no tiene voz ni a la hora de decidir su matrimonio de conveniencia ni a la hora de cambiar de esposo por el amor de éste. Sin embargo, sí son determinantes los deseos de los varones Seleuco y Antíoco, quienes actúan movidos, bien por deseos de alianza territorial, bien por amor, pero nada sabemos de lo que pensaba la joven Estratonice cuya voz nunca se oye, ni siquiera cuando se espera su veredicto en relación con el encierro de su padre.

Ignoramos, de otro lado, por qué obvia Plutarco en la biografia de Demetrio ${ }^{41} \mathrm{su}$ matrimonio con Lanasa, celebrado entre los años 292-1 a. C., quien le entregó como dote la isla de Corcira. En estos años, pese a que gozaba de gran popularidad como rey de Macedonia, gracias, en parte, a su matrimonio con File, aceptó la proposición de la mujer de Pirro que se habia separado de su marido cuando éste se casó con la princesa iliria Bircena. Pero no han de causar extrañeza las omisiones o deformaciones a que Plutarco somete, en ocasiones, la historia en función de sus propios intereses, no siempre diáfanos.

Sea cual fuere el motivo, las dos mujeres más importantes en la vida de Demetrio Poliorcetes fueron, sin duda alguna, su esposa File y su amante Lamia, ambas mayores que él en edad. Representa la primera el matrimonio por conveniencia -en realidad todas las consortes legitimas fueron desposadas por interés-, desde que le persuadiera su padre con una máxima modificada de Eurípides. La segunda ejemplifica la unión libre por amor que se manifiesta desde el momento en que Demetrio defiende a su "prostituta" de los ataques verbales de sus adversarios, como el de Lisímaco, y le permite comportarse de un modo un tanto déspota con sus súbditos. Resulta de interés particular el hecho de que la primera no tenga voz propia sino como intermediaria entre su marido y sus hermanos Plistarco y Casandro, de forma que constituye un elemento pacificador y virtuoso. Lamia, en

No así en Plut., Pyrrh. 10.7 donde se dice que Lanasa, necesitada de bodas reales se dirigió a

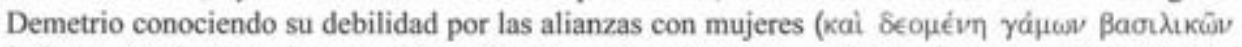

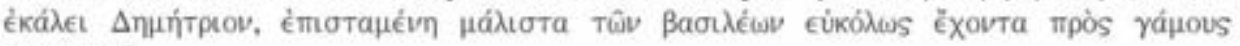

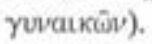


cambio, alza su voz e impone sus criterios, exige dinero para sus caprichos y consigue cuanto anhela de Demetrio. Así, la única mujer cuya personalidad se destaca de manera indiscutible es la compañera sentimental más afin al protagonista, Lamia, precisamente por su carácter semejante al de su amado. Es, en efecto, de la única mujer de la que se cuentan anécdotas, es, sin lugar a dudas, de la que más se habla y la única cuyos deseos y forma de ser se señalan abiertamente: es posesiva, apasionada y salvaje en el amor hasta el punto de dejar señales en el cuerpo de Demetrio; exigente y con poder de pedir dinero para fiestas a todo el mundo (lo cual es indicio de que gozaba del respaldo de Demetrio para sus actuaciones); obsequiada de modo superlativo, si hemos de creer la anécdota del jabón; terrible hasta el punto de ser llamada con el nombre de una máquina de guerra y ser motivo de los escritos de personajes importantes, pero también razonable y justa al tiempo que con el poder de ver cumplido su dictamen. Fue por todo ello, envidiada por las esposas y los amigos de Demetrio, Lamia, amada y feliz durante mucho tiempo.

Consecuencia inevitable de la poligamia practicada por Demetrio fue una descendencia prolija: de File tuvo a Antigono y Estratonice; de una mujer de Iliria a Demetrio el Flaco; de Ptolemaida a otro Demetrio, que reinó en Cirene; de Deidamía a Alejandro, que pasó su vida en Egipto y se dice, además, que tuvo de Eurídice otro hijo llamado Corrago:

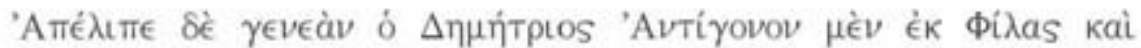

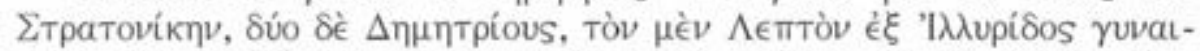

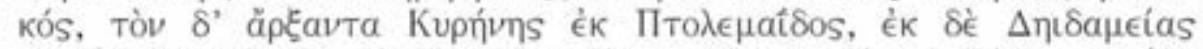

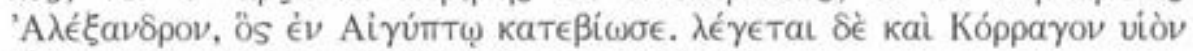

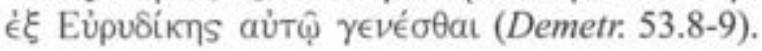

Así concluye Plutarco la vida del rey de acuerdo con los preceptos retóricos del género según los cuales se ha de señalar la muerte del personaje en cuestión, así como algunos detalles de su fortuna póstuma.

\section{BIBLIOGRAFIA}

AgUIL.AR, R.M".,

- "Plutarco y los médicos helenísticos", en A. Casanova (ed.), Plutarco e l'età ellenistica, Atti del convegno internazionale di studi, Firenze, 23-24 settembre 2004, Università degli studi di Firenze, 2004, pp. 417-434.

AGUILAR, R.M ${ }^{3}$.,

- "Mujeres bárbaras en Plutarco: Vidas de Lúculo y Pompeyo" en E. CALDERón, A. Morales, M. Valverde (eds.), Homenaje al profesor José Garcia López, Murcia, Koinós Lógos, 2006, pp. 27-34.

APIANO,

- Historia romana I, Introducción, traducción y notas de A. Sancho Royo, Madrid, 1980. 
BENEFIEL, R.R.J.,

- "Teaching by Example: Aetiology in Plutarch's De Mulierum Virtutibus" en PLOUTARCHOS, n. s., 1 (2003) 11-20.

BIELMAN, A.,

- Femmes en public dans le monde hellénistique, Lausanne, 2002.

BLOMQuist, K.,

- "From Olympias to Aretaphila: Women in Politics in Plutarch", en J. Mossman (ed), Plutarch and his Intellectual World, Londres, 1997, pp. 73-98.

Flaceliére, R.-Chambry. É.,

- Plutarque. Vies, Tome VI, texte établi et traduit par -, Paris, 1971.

Gallê Cejudo, R.,

- "Las virtudes de Pantea y su tratamiento en Plutarco" en Pérez Jiménez, A. \& CASADESÚs BORDOY, F. (eds.), Estudios sobre Plutarco: misticismo y religiones mistéricas en la obra de Plutarco, Actas del VII Simposio Español sobre Plutarco, Palma de Mallorca, 2001, pp. 507-518.

GonZẢlez Almenara, G,

- "El poder de la sexualidad femenina en el Pericles de Plutarco" en PÉrez JiménEz, A. \& CASADESÚS BORDOY, F. (eds.), Estudios sobre Plutarco: misticismo y religiones mistéricas en la obra de Plutarco, Actas del VII Simposio Español sobre Plutarco, Palma de Mallorca, 2001, pp. 379-388.

Helmbold, W.C.-O’NEIL. E.N.,

- Plutarch's Quotations, The American Philological Association, 1959.

Herrero Ingelmo, $\mathrm{M}^{\mathrm{m}} \mathrm{C}$.,

- Pausanias, Descripción de Grecia, Libros VII-X, Madrid, 1994.

Le Corsu, F.,

- Plutarque et les femmes dans les vies parallèles, Paris, 1981.

MACurdy, G.H.,

- Hellenistic Queens. A Study of Woman-Power in Macedonia, Seleucid Syria and Ptolemaic Egypt, Baltimore, 1932.

PAgE, T.E. (ed.),

- Diodorus of Sicily with an english translation by Francis R. Walton, volume XI, Loeb, 1957.

RusSEL. M. GEeR.,

- Diodorus of Sicily with an English translation by -, vol. X, Cambridge, 1962.

Simon, E.,

- Plutarque. Vies. Index des noms propres, tome XVI, Paris, 1983.

STADTER, PH.A.,

- Plutarch's Historical Methods. An Análisis of the Mulierum Virtudes, Harvard University Press, 1965. 
(Página deixada propositadamente em branco) 


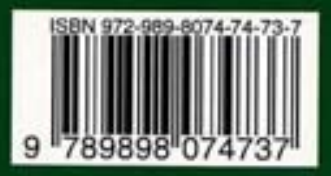

